\title{
Shoot chloride exclusion and salt tolerance in grapevine is associated with differential ion transporter expression in roots
}

\author{
Sam W Henderson', Ute Baumann², Deidre H Blackmore ${ }^{3}$, Amanda R Walker ${ }^{3}$, Rob R Walker ${ }^{3}$ and Matthew Gilliham ${ }^{\text {* }}$
}

\begin{abstract}
Background: Salt tolerance in grapevine is associated with chloride $\left(\mathrm{Cl}^{-}\right)$exclusion from shoots; the rate-limiting step being the passage of $\mathrm{Cl}^{-}$between the root symplast and xylem apoplast. Despite an understanding of the physiological mechanism of $\mathrm{Cl}^{-}$exclusion in grapevine, the molecular identity of membrane proteins that control this process have remained elusive. To elucidate candidate genes likely to control $\mathrm{Cl}^{-}$exclusion, we compared the root transcriptomes of three Vitis spp. with contrasting shoot $\mathrm{Cl}^{-}$exclusion capacities using a custom microarray.

Results: When challenged with $50 \mathrm{mM} \mathrm{Cl}^{-}$, transcriptional changes of genotypes 140 Ruggeri (shoot $\mathrm{Cl}^{-}$excluding rootstock), K51-40 (shoot $\mathrm{Cl}^{-}$including rootstock) and Cabernet Sauvignon (intermediate shoot $\mathrm{Cl}^{-}$excluder) differed. The magnitude of salt-induced transcriptional changes in roots correlated with the amount of $\mathrm{Cl}^{-}$accumulated in shoots. Abiotic-stress responsive transcripts (e.g. heat shock proteins) were induced in 140 Ruggeri, respiratory transcripts were repressed in Cabernet Sauvignon, and the expression of hypersensitive response and ROS scavenging transcripts was altered in K51-40. Despite these differences, no obvious $\mathrm{Cl}^{-}$transporters were identified. However, under control conditions where differences in shoot $\mathrm{Cl}^{-}$exclusion between rootstocks were still significant, genes encoding putative ion channels SLAH3, ALMT1 and putative kinases SnRK2.6 and CPKs were differentially expressed between rootstocks, as were members of the NRT1 (NAXT1 and NRT1.4), and CLC families.
\end{abstract}

Conclusions: These results suggest that transcriptional events contributing to the $\mathrm{Cl}^{-}$exclusion mechanism in grapevine are not stress-inducible, but constitutively different between contrasting varieties. We have identified individual genes from large families known to have members with roles in anion transport in other plants, as likely candidates for controlling anion homeostasis and $\mathrm{Cl}^{-}$exclusion in Vitis species. We propose these genes as priority candidates for functional characterisation to determine their role in chloride transport in grapevine and other plants.

Keywords: ABA signalling, ACA, CAX, mRNA, Salt overly sensitive (SOS), Woody perennial

\section{Background}

Grapevine (Vitis vinifera L.), used for wine, table grape and dried grape production, is an economically important crop plant that is moderately sensitive to salinity [1]. Grapevine salt stress symptoms include reduced stomatal conductance, reduced photosynthesis [2,3] and leaf burn [4], which are generally associated with increases in shoot chloride $\left(\mathrm{Cl}^{-}\right)$rather than sodium $\left(\mathrm{Na}^{+}\right)$concentrations

\footnotetext{
* Correspondence: matthew.gilliham@adelaide.edu.au

'Australian Research Council Centre of Excellence in Plant Energy Biology, School of Agriculture, Food and Wine, \& Waite Research Institute, University of Adelaide, PMB1, Glen Osmond, South Australia 5064, Australia Full list of author information is available at the end of the article
}

[3]. Reduced vigour [5] and reduced yield [6] are further effects of salt stress, with a strong positive correlation between the two [5]. Certain non-vinifera Vitis spp. rootstocks are used commercially to constrain shoot $\mathrm{Cl}^{-}$accumulation and confer improved salt tolerance to grafted $V$. vinifera scions $[7,8]$. Despite a detailed understanding of the physiology of shoot $\mathrm{Cl}^{-}$accumulation in grapevine and other plants, the genes responsible for this process across the plant kingdom are not known [9]. This is in contrast to the control of long-distance $\mathrm{Na}^{+}$transport in plants where numerous reports have targeted known genes in order to improve the salt tolerance of plants, particularly cereals e.g. [10-13]. Due to extensive natural variation in the shoot $\mathrm{Cl}^{-}$exclusion capacity of Vitis spp. 
$[14,15]$ grapevine represents an ideal model to identify candidate genes involved in controlling shoot $\mathrm{Cl}^{-}$ exclusion.

Solutes travel from the roots to the shoot in the xylem. Physiological studies using radiotracers and fluorescent dyes in grapevine have indicated that the transfer of solutes to the xylem apoplast involves a symplastic step, and that rootstocks confer $\mathrm{Cl}^{-}$exclusion to a grafted scion by reducing net xylem loading of $\mathrm{Cl}^{-}[15,16]$. Patch clamp studies of xylem parenchyma protoplasts identified the passive quickly activating anion conductance (X-QUAC) as capable of catalysing the majority of $\mathrm{Cl}^{-}$flux to the xylem of barley roots [17]. $\mathrm{Cl}^{-}$entry to the root xylem is down-regulated by abscisic acid (ABA), as demonstrated by ${ }^{36} \mathrm{Cl}^{-}$fluxes in excised roots and whole seedlings of barley [18], and reduces X-QUAC of maize xylem parenchyma cells [19]. Given that ABA rises in concentration in plant roots exposed to salt stress [20], anion transporters expressed in cells that surround the root xylem, especially those that change activity when plants are salt treated are likely to be good targets to explore for improving our understanding how shoot $\mathrm{Cl}^{-}$exclusion is conferred.

There have been a limited number of studies that have provided insights to the genetic elements that control long-distance transport of $\mathrm{Cl}^{-}$. Like grapevine, Citrus spp. are moderately salt-sensitive woody perennial crops frequently grown on salt-excluding rootstocks. Brumos et al. [21] compared the partial leaf transcriptomes of Citrus rootstocks Cleopatra mandarin (a good shoot $\mathrm{Cl}^{-}$ excluder) and Carrizo citrange (a poor shoot $\mathrm{Cl}^{-}$excluder) exposed to $\mathrm{NaCl}$ and $\mathrm{KCl}$ stress using a cDNA microarray covering 6,875 putative unigenes. They concluded that a nitrate $\left(\mathrm{NO}_{3}^{-}\right)$transporter with homology to GmNRT1-2 from soybean was differentially expressed between rootstocks and therefore was deemed a candidate gene for influencing $\mathrm{Cl}^{-}$movement. Using the same germplasm, Brumos et al. [22] used quantitative PCR to measure root expression of three candidate genes for the control of long-distance $\mathrm{Cl}^{-}$transport derived from the literature. Candidates included a homolog of a cation chloride co-transporter (CcCCC1), CcICln1 (a putative regulator of chloride channel conductance) and CCSLAH1, a homolog of the plant guard cell slow anion channels (SLAC) [22]. Of these genes SLAH1 was more highly expressed in the chloride accumulating rootstock under $90 \mathrm{mM} \mathrm{NaCl}$ stress. In guard cells, SLAC chloride channels meditate ABA induced passive $\mathrm{Cl}^{-}$efflux causing stomatal closure [23,24]. SLAC homologs (SLAH) in plant roots are therefore particularly interesting candidates for xylem loading of $\mathrm{Cl}^{-}$, but their role in roots remains uncharacterised. $C C C$ was proposed to regulate retrieval of $\mathrm{Na}^{+}, \mathrm{K}^{+}$and $\mathrm{Cl}^{-}$from the Arabidopsis root xylem but was not regulated transcriptionally by salt $[22,25]$.
Furthermore, questions remain as to how CCC can act directly in xylem loading on the plasma membrane due to unfavourable electrochemical gradients [9]. ICln1 homologs from rat and Xenopus laevis elicit $\mathrm{Cl}^{-}$currents in voltage clamp experiments [26]. In Citrus, ICln1 exhibited strong repression in the $\mathrm{Cl}^{-}$excluder after application of $4.5 \mathrm{mM} \mathrm{Cl}^{-}$[22]. However, ICln proteins from plants remain uncharacterised. Whilst these genes are good candidates for regulating $\mathrm{Cl}^{-}$transport in Citrus, analyses of entire root transcriptomes is likely to provide a more complete list of factors that mediate long-distance transport of $\mathrm{Cl}^{-}$.

Gene expression studies of $V$. vinifera have been greatly aided by the draft genome sequence of Pinot Noir inbred line PN40024 [27,28]. These studies have concentrated on berry development $[29,30]$, leaf responses to heat stress [31] and to UV radiation [32]. The most comprehensive grapevine expression study to date compared the transcriptome of 54 samples representing different vegetative and reproductive organs at various developmental stages [33]. Although abiotic stress was not analysed in this study, grapevine roots were found to express more organspecific transcripts than leaves [33]. This is consistent with findings from Tillett et al., [34] who compared large-scale EST libraries from roots and shoots of Cabernet Sauvignon and identified 135 root enriched transcripts. These findings indicate that shoot expression analyses of grapevine, while useful, might not give a complete picture of root gene expression patterns, and therefore studies into root responses to abiotic stresses are required. Two microarray studies have examined the effect of salinity stress on transcript levels of Cabernet Sauvignon shoot tips [35,36]. Increased levels of a transcript encoding a putative NRT were observed, while decreased expression of a chloride channel $(C L C)$ with sequence similarity to Arabidopsis $A t C L C-d$ was detected by two probe sets, but this was not statistically significant [36].

We performed a comparative microarray of mRNAs derived from roots of salt stressed and control Cabernet Sauvignon, 140 Ruggeri and K51-40 rooted leaves as an unbiased method to identify candidates for long-distance transport of $\mathrm{Cl}^{-}$. We aimed to test the hypothesis that the differences in $\mathrm{Cl}^{-}$exclusion between rootstocks 140 Ruggeri and K51-40 could be due to expression differences in genes that encode membrane transport proteins which facilitate root-to-shoot $\mathrm{Cl}^{-}$translocation. The identification of genes that prevent excessive shoot $\mathrm{Cl}^{-}$accumulation in grapevine will facilitate continued rootstock development by providing genetic markers for rootstock breeding programs. Furthermore, this study will aid a greater understanding of plant $\mathrm{Cl}^{-}$homeostasis by using grapevine as a model species to elucidate genes that underpin the $\mathrm{Cl}^{-}$exclusion trait in plants in general. 


\section{Methods}

\section{Preparation of rooted-leaves}

Grapevine, being a woody perennial crop, is challenging to use in controlled conditions experiments, especially where large amounts of material and multiple replicates are required. We therefore used the method of Schachtman and Thomas [37] where leaves are excised from a parent plant and grown as rooted-leaves. This is consistent with previous studies of $\mathrm{Cl}^{-}$accumulation in vines, where it was demonstrated that root and leaf phenotypes acquired with this system are similar to field observations $[15,16]$. Rooted leaves were established from pot-grown grapevines of K51-40 (Vitis champinii X Vitis riparia), 140 Ruggeri (Vitis berlandieri X Vitis rupestris) and Cabernet Sauvignon (Vits vinifera) established from cuttings and maintained in a glasshouse as described previously [15]. After approximately 3 weeks, rooted-leaves were transferred to aerated hydroponic tanks containing modified Hoagland Solution with the following nutrients (in $\mathrm{mM}$ ) for a twoweek pre-treatment period: $\mathrm{KNO}_{3}, 1.0 ; \mathrm{Ca}\left(\mathrm{NO}_{3}\right)_{2} \cdot 4 \mathrm{H}_{2} \mathrm{O}$, 1.0; $\mathrm{MgSO}_{4} \cdot 7 \mathrm{H}_{2} \mathrm{O}, 0.4 ; \mathrm{KH}_{2} \mathrm{PO}_{4}, 0.2 ; \mathrm{H}_{3} \mathrm{BO}_{3}, 4.6 \times 10^{-2}$; $\mathrm{MnCl}_{2} \cdot 4 \mathrm{H}_{2} \mathrm{O}, 9.1 \times 10^{-3} ; \mathrm{ZnSO}_{4} \cdot 7 \mathrm{H}_{2} \mathrm{O}, 7.6 \times 10^{-4} ; \mathrm{CuSO}_{4}$. $5 \mathrm{H}_{2} \mathrm{O}, 3.2 \times 10^{-4} ; \mathrm{Na}_{2} \mathrm{MoO}_{4} \cdot 2 \mathrm{H}_{2} \mathrm{O}, 2.4 \times 10^{-4}$; EDTA-Fe$\mathrm{Na}, 7.1 \times 10^{-2}(\mathrm{pH} 6.5)[15]$.

\section{Response of intact rooted-leaves to short term salinity}

Rooted-leaves of K51-40, 140 Ruggeri and Cabernet Sauvignon were subjected to nutrient solution only (control) or to $50 \mathrm{mM} \mathrm{Cl}^{-}\left(\mathrm{Na}^{+}: \mathrm{Ca}^{2+}: \mathrm{Mg}^{2+}=6: 1: 1\right)$ in nutrient solution for 4 days. At harvest, the rooted-leaves of each genotype were washed in de-ionised water, blotted dry with paper towel, weighed, then separated into lamina, petiole and roots. Fresh weights of all plant parts were also obtained. Samples were divided equally for RNA extraction and ion composition analysis. Samples for RNA extraction were snap frozen in liquid nitrogen and stored at minus $80^{\circ} \mathrm{C}$. Root, petiole and lamina samples for ion analysis were weighed before being dried in an oven at $60^{\circ} \mathrm{C}$ and retained for $\mathrm{Cl}^{-}$analysis.

For stele and cortex expression studies roots were salttreated and harvested as described above, lateral roots were removed from main roots and then cortex was stripped from stele of the main root using fine tweezers. Three biological replicates were harvested, each consisting of dissected tissue from three rooted-leaves. Tissue samples were immediately frozen in liquid nitrogen and stored at minus $80^{\circ} \mathrm{C}$ for RNA extraction.

\section{Ion analyses}

Laminae, petiole and root samples were dried at $60^{\circ} \mathrm{C}$ for at least $72 \mathrm{~h}$ and ground to a fine powder using a mortar and pestle. $\mathrm{Cl}^{-}$concentration was measured by silver ion titration with a chloridometer (Model 4425150, Buchler Instruments, Lenexa, Kansas, USA) from extracts prepared by digesting 20-100 mg dry samples in $4 \mathrm{~mL}$ of acid solution containing $10 \%(\mathrm{v} / \mathrm{v})$ acetic acid and $0.1 \mathrm{M}$ nitric acid overnight before analysis.

\section{RNA extraction}

Frozen root tissues were ground to a fine powder in liquid nitrogen using a mortar and pestle. RNA was extracted using the Spectrum Plant Total RNA Kit (Sigma, St. Louis, Missouri, USA) following the manufacturer's protocol. RNA was DNase I treated with Turbo DNAfree (Life Technologies, Carlsbad, California, USA) for 1 hour at $37^{\circ} \mathrm{C}$ to remove contaminating genomic DNA. RNA was precipitated at minus $80^{\circ} \mathrm{C}$ overnight in 5 volumes of $100 \%$ ethanol $(\mathrm{v} / \mathrm{v})$ and $1 / 10$ volumes of $3 \mathrm{M}$ $\mathrm{NaOAC}$. After ethanol precipitation, RNA was resuspended in nuclease free water and analysed on a NanoDrop 1000 spectrophotometer (Thermo Fisher Scientific, Waltham, Massachusetts, USA). Only RNA samples with $260 / 280$ and $260 / 230$ absorbance ratios greater than 1.8 were used. RNA integrity was screened on a Bioanalyzer 2100 (Agilent Technologies, Santa Clara, California, USA) and only RNA samples with an RNA integrity number (RIN) above 8.5 were used.

\section{Microarray chip design, labelling and hybridisation}

Custom $8 x 60 \mathrm{~K}$ gene expression microarrays were designed using eArray (Release 7.6) (Agilent Technologies). Oligonucleotide probes (60-mers) were designed against 26,346 annotated $V$. vinifera transcripts from the $12 x$ Genoscope build available from http://www.genoscope. cns.fr/externe/GenomeBrowser/Vitis/. The Agilent 60mer probe format is considered more tolerant to sequence mismatches than 25-mers, and more suitable for analysis of polymorphic DNA sequences [38]. Also, the use of a custom Agilent expression array enabled us to print a subset of probes for 90 putative anion transporters multiple times on the array (Additional file 1). This multi-probe approach increases the robustness of the expression values obtained when the probes for these genes are averaged. Probes that detect differential gene expression many times show a greater probability of genuine differential expression when the B-statistic probability (log-odds) of differential gene expression is calculated. The higher the B-statistic, the greater the chance that the gene is differentially expressed (B-statistic $=0$ represents 50:50 chance of differential gene expression).

Twenty-two microarrays were used which consisted of 4 biological replicates for Cabernet Sauvignon $\left( \pm 50 \mathrm{mM} \mathrm{Cl}^{-}\right)$, 4 biological replicates of $\mathrm{K} 51-40\left( \pm 50 \mathrm{mM} \mathrm{Cl}^{-}\right)$and 3 biological replicates of 140 Ruggeri $\left( \pm 50 \mathrm{mM} \mathrm{Cl}^{-}\right)$. Each biological replicate consisted of roots from 4 rooted-leaves pooled together. Single colour labelling, hybridisations and image analysis were performed at the Ramaciotti 
Centre for Gene Function Analysis (University of New South Wales, Australia).

\section{Functional annotation of genes}

Gene functional annotation, which included InterPro descriptions, Gene Ontology terms and Arabidopsis orthologs, was obtained from BioMart at EnsemblPlants (plants.ensembl.org/biomart/martview/). Additional functional annotation was gathered from Grimplet et al. [39], and this annotation was used for the tables and figures presented in this manuscript.

\section{Microarray data analysis}

Scanned images were analysed with Feature Extraction Software 10.7.3 (Agilent Technologies, Santa Clara, California, USA) and the Cy3 median signal intensities for each spot on the arrays were imported into $\mathrm{R}$ for further processing. The data was $\log (2)$ transformed and quantile normalized. Since the microarray hybridizations were performed at different dates we observed batch effects that we corrected for with the ComBat package [40]. The quality of the microarray hybridisation and reproducibility amongst biological replicates was validated using arrayQualityMetrics version 3.12.0 [41]. Differentially expressed genes were identified using the Linear Model for Microarray Data (LIMMA) package [42], and the Benjamini and Hochberg correction method was applied to account for multiple testing [43]. To filter the probes, the probe sequences were blasted against the predicted cDNAs of the $12 x V 1$ genome sequence at EnsemblPlants. Probes with an e-value $\geq 1 \times 10^{-10}$ and probes that showed no blast hit were excluded from the initial analyses. Gene expression changes were considered significant when a threshold fold change of greater than or equal to 1.41 was reached (log (2) FC \pm 0.5 ) and a false discovery rate (FDR) corrected probability of $P \leq 0.05$. The raw data for the microarray are available at the Gene Expression Omnibus database (http://www.ncbi.nlm.nih.gov/geo/) under accession number GSE57770.

Hierarchical clustering and co-expression analysis was performed using Genesis 1.7.6 [44] using tab delimited text files of the $\log (2)$ fold change values of gene expression of averaged probes. Transcripts and experiments were clustered using the average linkage method. Singular enrichment analysis was performed using Agrigo [45]. At the time of writing, the Agrigo server is incompatible with $12 \mathrm{xV} 1 \mathrm{~V}$. vinifera gene IDs. Therefore transcripts that were differentially expressed (identified after filtering) were entered into the Agrigo server using the $12 \mathrm{xV0}$ transcript ID's (Genoscope). The hypergeometric method with Hochberg (FDR) multi-test adjustment was used to identify statistically significant GO terms $(P<0.05)$.

\section{Phylogenetic analyses}

$V$. vinifera protein sequences of interest were obtained from EnsemblPlants using the $12 \mathrm{xV} 1$ gene IDs. $V$. vinifera amino acid sequences were used as a query in a proteinprotein BLAST (blastp) at the National Centre for Biotechnology Information (NCBI) against non-redundant protein sequences limited to Arabidopsis thaliana (taxid: 3702). Arabidopsis sequences with the best total score were reciprocally blasted at EnsemblPlants against the Vitis vinifera peptide database. Arabidopsis and grapevine sequences that were obtained using this approach were aligned using Clustal W2 [46]. Phylogenetic trees were generated with Geneious 6.1.2 (Biomatters) using the neighbour-joining method and the Jukes-Cantor genetic distance model. A consensus tree was generated by resampling 1000 times using the bootstrap method. Branch lengths are proportional to the amount of divergence between nodes in units of substitutions per site. Gene identifiers for the protein sequences used are shown in Additional file 2, while the multiple sequence alignment is shown in Additional file 3.

\section{Quantitative real-time PCR (qRT-PCR)}

One microgram of total RNA was reverse transcribed in a $20 \mu \mathrm{L}$ reaction using iScript cDNA Synthesis Kit (Bio-Rad, Hercules, California, USA). The procedure was modified from the manufacturer's to include an initial RNA denaturation step of $65^{\circ} \mathrm{C}$ for 5 minutes then incubation on ice for 1 minute, and cDNA synthesis step of $42^{\circ} \mathrm{C}$ for 1 hour. cDNA was diluted 1 in 5. Two microliters of CDNA was used as a template for PCR and qRT-PCR reactions. PCR targets were first amplified from cDNA using KAPA taq (KAPA Biosystems, Woburn, Massachusetts, USA) following manufacturer's procedures. Fragments of the correct size and target were confirmed by agarose gel and sequencing. PCR fragments, or linearised plasmid containing the PCR fragment, were serially diluted and used as a template for qRT-PCR in duplicate. Standard curves were generated using iCycler iQ optical system software version 3.1 (Bio-Rad), which also calculates the reaction efficiency of each primer pair using the formula $\mathrm{E}=10^{-1 / \text { slope }}$. qRT-PCR was performed on a Bio-Rad iCycler. Reactions consisted of $250 \mathrm{nM}$ forward and reverse primer, 1x KAPA SYBR FAST qPCR Master Mix (KAPA Biosystems), and $2 \mu \mathrm{L}$ of diluted cDNA. Reactions were performed in triplicate following a three-step protocol consisting of 40 cycles of the following: $95^{\circ} \mathrm{C} 15 \mathrm{sec}$, $56^{\circ} \mathrm{C} 20 \mathrm{sec}, 72^{\circ} \mathrm{C} 10 \mathrm{sec}$ (plus data acquisition). Melt curve analysis was performed by heating PCR products from $52^{\circ} \mathrm{C}$ to $92^{\circ} \mathrm{C}$ for 20 seconds increasing at $0.5^{\circ} \mathrm{C}$ per cycle with continuous fluorescence detection. Relative expression ratios were calculated using the primer pair efficiency and the formula described by Pfaffl [47], with the geometric mean of VvActin1, VvUbiquitin-L40 and 
$V v$ Elongation-factor-1- $\alpha$ used as the reference for normalisation [48]. Normalised expression values were transformed to $\log (2)$ values for comparison with microarray data. Primers used for qRT-PCR are listed in Additional file 4. Primers were designed using Primer3 [49]. Primers were designed to amplify single products from the target gene between 140 and 250 bp with an optimal GC content of $50 \%$ and, where possible, designed to span an intron to ensure that cDNA targets were amplified. Before their use, primers were screened for potential non-selective amplification using PrimerBLAST at NCBI against the Refseq RNA database limited to Vitis species.

\section{Results}

Salt treatment, grapevine growth and ion accumulation Following 4-days of $50 \mathrm{mM} \mathrm{Cl}^{-}$treatment, roots of 140 Ruggeri retained significantly more $\mathrm{Cl}^{-}$compared to those of Cabernet Sauvignon and K51-40 (Figure 1A). Conversely, Cabernet Sauvignon and K51-40 petioles and laminae accumulated significantly more $\mathrm{Cl}^{-}$compared to 140 Ruggeri (Figure $1 \mathrm{~B}$ and C). K51-40 accumulated the highest amount of $\mathrm{Cl}^{-}$in aerial tissues under salt stress (Figure $1 \mathrm{~B}$ and $\mathrm{C}$ ). Under control conditions, 140 Ruggeri also accumulated significantly less petiole and laminae $\mathrm{Cl}^{-}$than $\mathrm{K} 51-40$, indicating that the $\mathrm{Cl}^{-}$exclusion mechanism may be active in low $\mathrm{Cl}^{-}$conditions (Figure $1 \mathrm{~B}$ and $\mathrm{C}$ ). Overall, the shoot $\mathrm{Cl}^{-}$accumulation of varieties can be expressed as 140 Ruggeri < Cabernet Sauvignon $<$ K51-40.

\section{Validation of microarray data using real-time quantitative PCR (qRT-PCR)}

To validate the microarray expression data and further quantify mRNA expression levels, we measured the expression of 12 genes by qRT-PCR and compared the datasets. Expression ratios of genes from control and $50 \mathrm{mM} \mathrm{Cl}^{-}$treated samples were analysed by linear regression and an $R^{2}$ value of 0.88 was observed, indicating good correlation (Additional file 5a). Similarly, qRTPCR and microarray ratios for 12 genes were compared between varieties under control conditions, which provided an $\mathrm{R}^{2}$ value of 0.89 , also demonstrating good correlation (Additional file $5 \mathrm{~b}$ ).

\section{Differentially expressed genes due to chloride stress}

Following $\mathrm{Cl}^{-}$stress 1361 unique genes were differentially expressed in at least one grapevine variety (Figure 2, Additional file 6). The number of differentially expressed genes due to $\mathrm{Cl}^{-}$treatment was positively correlated with $\mathrm{Cl}^{-}$accumulation in shoot tissues. The $\mathrm{Cl}^{-}$accumulator $\mathrm{K} 51-40$ had the highest number of $\mathrm{Cl}^{-}$responsive transcripts (817), followed by the intermediate accumulator Cabernet Sauvignon (511), while the $\mathrm{Cl}^{-}$ excluder 140 Ruggeri had the least number of $\mathrm{Cl}^{-}$responsive transcripts (252) (Figure 2). This correlation is consistent with findings in Citrus leaves when salt tolerant and sensitive rootstocks were compared after salt stress [21].

\section{Cluster analysis}

The transcript profiles of Cabernet Sauvignon, 140 Ruggeri and $\mathrm{K} 51-40$ roots exposed to high $\mathrm{Cl}^{-}$were grouped by hierarchical clustering (Figure 3). 140 Ruggeri and Cabernet Sauvignon had the most similar transcriptional response to $\mathrm{Cl}^{-}$in roots, while the $\mathrm{Cl}^{-}$includer $\mathrm{K} 51-40$ had a unique response (Figure 3, top dendrogram). Gene clusters were examined by singular enrichment analysis (SEA) of gene ontology (GO) terms. Three clusters of interest showed enrichment of GO biological processes (Figure 3). Other gene clusters showed no significant enrichment of GO terms.

In 140 Ruggeri, $\mathrm{Cl}^{-}$treatment induced the expression of transcripts involved in abiotic stress tolerance (Figure 3, Cluster A), including glutathione-S-transferases (GST)
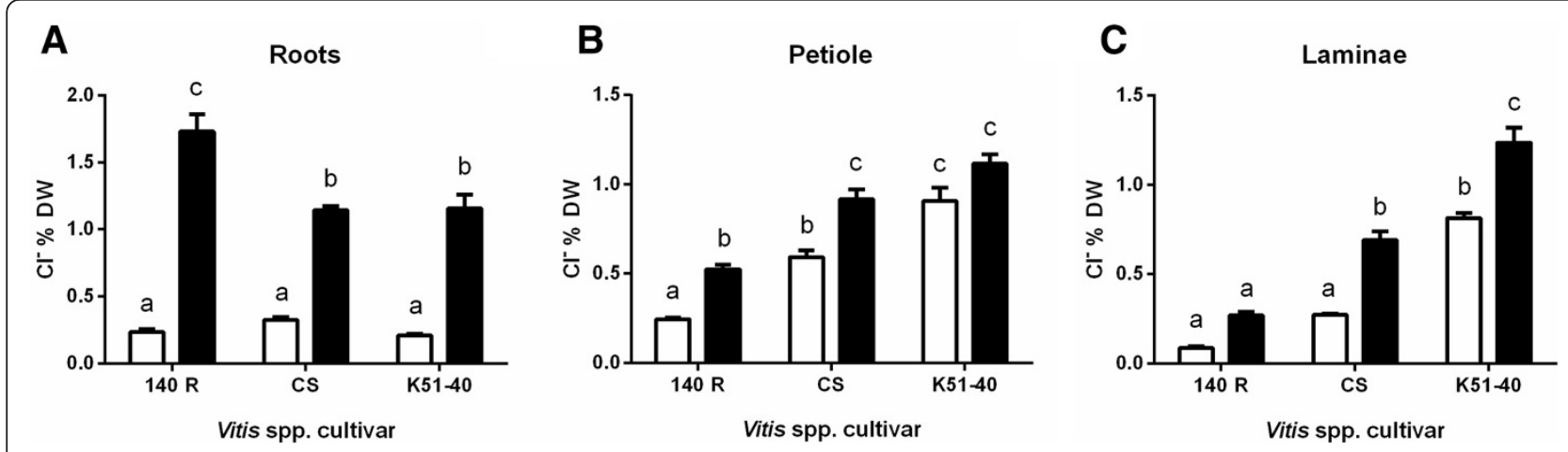

Figure 1 Differential chloride accumulation in tissues of different Vitis spp. Chloride concentration (\% dry weight) in the roots (A), petiole (B) and laminae (C) of hydroponically grown rooted-leaves under control (white bars) or $50 \mathrm{mM} \mathrm{Cl}^{-}$(black bars) conditions. Bars represent the mean \pm SEM of 4 biological replicates. Statistical significance was determined by one-way ANOVA with Bonferroni post-hoc test $(P<0.05)$. CS = Cabernet Sauvignon, $140 \mathrm{R}=140$ Ruggeri. 


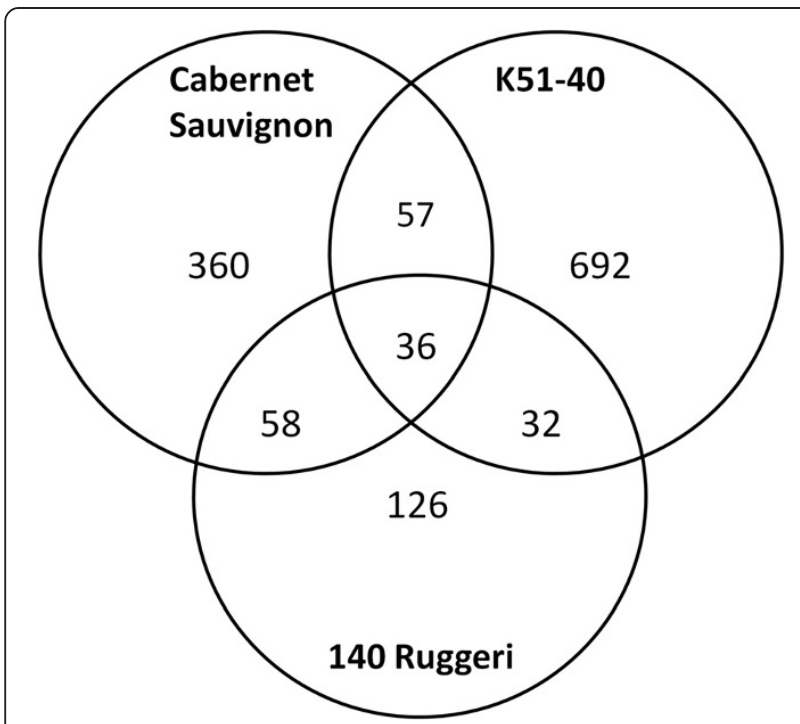

Figure 2 Transcriptomic response of Vitis spp. to $50 \mathrm{mM} \mathrm{Cl}^{-}$ treatment. Venn diagram showing the number of significantly differentially expressed unique transcripts predicted by the 12xV1 annotation of the $V$. vinifera genome in Cabernet Sauvignon, 140 Ruggeri and $\mathrm{K} 51-40$ roots under $50 \mathrm{mM} \mathrm{Cl}^{-}$stress. Significance was determined as $P<0.05, \geq 1.41$-fold change.

and heat shock proteins (HSP) (Additional file 7). Overexpression of GSTs in tobacco enhances growth under salt stress [50], while HSPs act as molecular chaperones that help maintain correct protein conformation under abiotic stress [51]. These unique trancriptional changes might enable 140 Ruggeri to perform better under salt stress relative to other grapevine genotypes.

In $\mathrm{K} 51-40, \mathrm{Cl}^{-}$treatment repressed genes involved in the hypersensitive response and flavonoid biosynthesis (Figure 3, Cluster B; Additional file 8). Flavonoids have diverse roles in plants including scavenging of reactive oxygen species (ROS) and pathogen defence [52]. Under salt stress, leakage of photosynthetic and respiratory electrons may react with oxygen, leading to ROS production and subsequent oxidative stress [53]. Therefore the transcriptional regulation of flavonoid biosynthesis in K51-40 might prevent damage from excessive ROS production. In Cabernet Sauvignon, $\mathrm{Cl}^{-}$treatment repressed mitochondrial specific transcripts, such as NADH dehydrogenases, c-type cytochromes and pentatricopeptide repeat (PPR) domain proteins (Figure 3, Cluster C; Additional file 9). Transcriptional repression of respiratory transcripts in Cabernet Sauvignon probably functions to reduce ROS production.

The stress-inducible phytohormone ABA restricts anion entry to the root xylem [18] and inward anion currents (anion efflux) from xylem parenchyma protoplasts from barley [17] and maize [19]. We therefore investigated whether high $\mathrm{Cl}^{-}$treatment reduces the expression of genes likely to facilitate $\mathrm{Cl}^{-}$transport to aerial tissues of 140 Ruggeri. Only four membrane transporters were repressed in 140 Ruggeri upon $\mathrm{Cl}^{-}$treatment and none were predicted to facilitate anion movement across membranes (Additional file 10).

\section{Transcriptional differences between grapevine varieties} under control conditions

Given that $\mathrm{Cl}^{-}$accumulation in shoot tissues was significantly different between grapevine varieties in the absence of salt stress (Figure $1 \mathrm{~B}$ and $\mathrm{C}$ ), we hypothesised that there might be a difference in gene expression of anion transporters under control conditions. Under these conditions, 4527 genes were differentially expressed between 140 Ruggeri and K51-40 with approximately half (2310 genes) being lower in 140 Ruggeri (Additional file 11). Genes encoding 214 membrane integral proteins were expressed differently between roots of K51-40 and 140 Ruggeri (Additional file 12). Multigene families have been proposed as regulators of salt tolerance and anion homeostasis in plants, including NRT, ALMT, SLAH and $C L C[9,54]$. Members from these and other gene families encoding membrane proteins, as well as possible regulatory proteins, that were expressed differently between rootstocks, are summarised (Table 1) and described below. As an alternative analysis, genes with a high B-statistic (log-odds) for differential expression between rootstocks are listed in Table 2.

\section{NRT/POT}

The NRT or proton dependent oligopeptide (POT) gene family is involved in the acquisition and whole plant homeostasis of nitrogen; different family members transport $\mathrm{NO}_{3}{ }^{-}$, amino acids and various peptides [55]. In our study, 8 NRT1 genes were expressed differently between rootstocks (Table 1). Grapevine NRT1 gene family members were poorly annotated in functional databases. To assign putative functions, we produced a phylogeny of the grapevine NRTs uncovered in our microarray screen using Arabidopsis NRT1s. Homologs of AtNRT1.4, AtNRT1.11, nitrate excretion transporter 1 (AtNAXT1), AtNAXT2 and glucosinolate transporter 1 (AtGTR1) were identified, as well as three other Vitis NRTs with uncharacterised Arabidopsis homologs (Figure 4). Two grapevine NRTs homologous to Arabidopsis AtNRT2.5 and AtNRT2.7, as well as a homolog of Arabidopsis oligopeptide transporter 4 (OPT4) were more abundantly expressed in 140 Ruggeri (Table 1). Differential expression of VvNAXT1, $V v N A X T 2, V v N R T 1.11$ (all higher in 140 Ruggeri) and VvNRT1.4 (higher in K51-40) was also highly significant (Table 2).

In Arabidopsis roots, AtNRT1.8 is induced and AtNRT1.5 repressed by salt and cadmium stress [56]. AtNRT1.5 is the only NRT1 isoform with a confirmed role in root xylem loading of $\mathrm{NO}_{3}^{-}$[57], and mutants of atnrt1.5 grow 


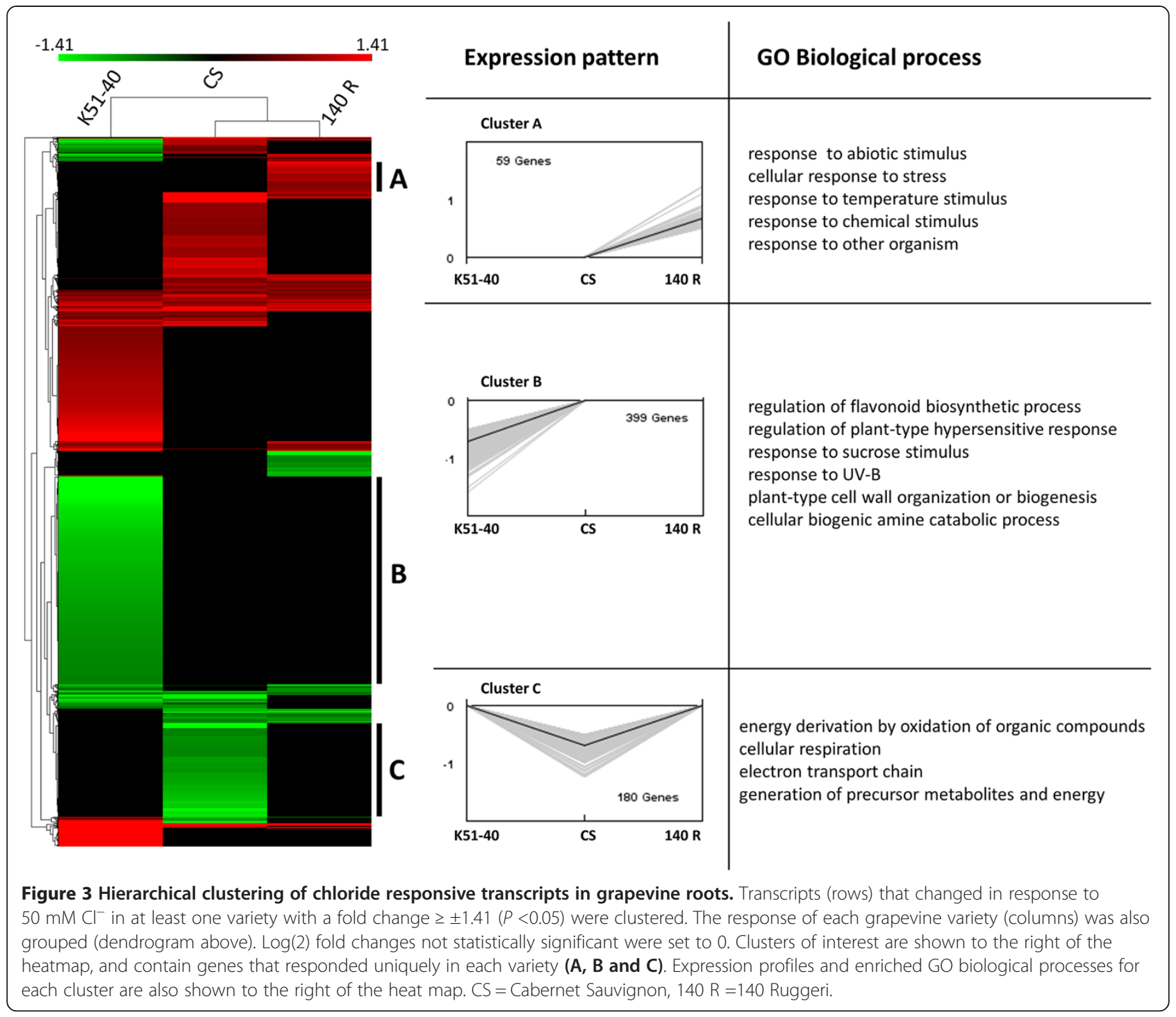

better under $\mathrm{NaCl}$ stress than wildtype [58]. Conversely, AtNAXT1 effluxes $\mathrm{NO}_{3}^{-}$under acid load, and is regulated at the post-transcriptional level [59]. We further investigated expression patterns of Vitis orthologs of these genes. $V v N R T 1.8$ and $V v N R T 1.5$ were identified phylogenetically (Figure 4). They were oppositely regulated by salt stress in Cabernet Sauvignon and 140 Ruggeri, but not K51-40, although the expression changes were small (Figure 5A and B). VvNAXT1 was unresponsive to salt in all three genotypes (Figure $5 \mathrm{C}$ ), which is consistent with the response of its homolog in Arabidopsis [59]. Interestingly, $V v N R T 1.4$ was strongly repressed ( 3 fold) by salt stress in K51-40 (Figure 5D). In spite of these differences in salt response, the largest transcriptional differences in grapevine NRT1 mRNAs were observed between genotypes under control conditions, especially between the contrasting rootstocks 140 Ruggeri and K51-40 (Figure 5E - H). This suggests of a role of some of these genes in $\mathrm{Cl}^{-}$exclusion in the absence of stress (Figure 6). Arabidopsis AtNRT1.5 is considered important for plant salt tolerance [58], possibly due a role in anion loading to the xylem [57]. In grapevine, $V v N R T 1.5$ was not preferentially expressed in the root stele under salt stress (Additional file 13), which contrasts with AtNRT1.5 [57]. Furthermore, VvNRT1.5 was more abundant in 140 Ruggeri than K51-40 (Figure 5F; Figure 6B). These data reduce the likelihood of VvNRT1.5 having a role in xylem loading of $\mathrm{Cl}^{-}$in grapevine. Based on transcriptional data, we suggest that $V v N R T 1.4$ is the best NRT1 candidate for xylem loading of $\mathrm{Cl}^{-}$due to a much greater abundance in K51-40 roots under control conditions (Figure 5D; Figure 6C).

\section{ALMT}

Chelation of toxic aluminium in the rhizosphere by the efflux of organic acids from roots is facilitated by plasma membrane aluminium-activated malate transporters 
Table 1 Differentially expressed genes between contrasting rootstocks encoding putative solute transporters under control conditions

\begin{tabular}{|c|c|c|c|c|c|c|}
\hline Probe ID & 12xV1 blast hit & $12 \times V 0$ gene ID & $\begin{array}{l}\text { Arabidopsis } \\
\text { homolog }\end{array}$ & $\begin{array}{l}\log (2) \mathrm{FC} \\
140 \mathrm{R}- \\
\mathrm{K} 51-40\end{array}$ & p-value & Functional annotation \\
\hline CUST_15333_17284 & VIT_02s0012g01270 & GSVIVT01013161001 & AT4G17870 & 1.41 & 1.11E-09 & Abscisic acid receptor PYL1 RCAR11 \\
\hline NG2_36172_20391 & VIT_06s0080g00170 & GSVIVT01036162001 & AT1G08440 & -0.69 & $3.02 \mathrm{E}-04$ & Aluminum activated malate transporter 1 \\
\hline CUST_44694_7793 & VIT_06s0009g00450 & GSVIVT01037570001 & AT1G08440 & 0.78 & $1.90 \mathrm{E}-03$ & Aluminum activated malate transporter 1 \\
\hline CUST_46237_21897 & VIT_08s0105g00250 & GSVIVT01011148001 & AT3G11680 & 1.30 & $2.51 \mathrm{E}-04$ & Aluminum activated malate transporter 1 \\
\hline CUST_8680_62299 & VIT_11s0052g00320 & GSVIVT01029283001 & AT4G29900 & -0.70 & $3.31 \mathrm{E}-04$ & $\begin{array}{l}\text { Calcium ATPase } 10 \text { (ACA10), } \\
\text { plasma membrane }\end{array}$ \\
\hline NG2_12175_47390 & VIT_07s0129g00180 & GSVIVT01000123001 & AT4G37640 & 0.58 & $8.86 \mathrm{E}-03$ & Calcium ATPase 2 (ACA2), plasma membrane \\
\hline CUST_16133_33172 & VIT_07s0129g00110 & GSVIVT01000116001 & AT4G37640 & 0.66 & $1.65 \mathrm{E}-02$ & Calcium ATPase 2 (ACA2), plasma membrane \\
\hline NG2_35892_10569 & VIT_06s0004g06570 & GSVIVT01024741001 & AT3G51860 & 1.44 & $5.00 \mathrm{E}-12$ & Calcium/proton exchanger CAX3 \\
\hline CUST_50946_56104 & VIT_02s0025g04520 & GSVIVT01019868001 & AT1G12580 & 0.70 & $2.43 \mathrm{E}-05$ & $\begin{array}{l}\text { Calcium-dependent protein kinase } 1 \\
\text { CPK protein kinase }\end{array}$ \\
\hline CUST_17465_49753 & VIT_08s0032g00780 & GSVIVT01022524001 & AT2G38910 & 0.52 & $2.67 \mathrm{E}-02$ & Calcium-dependent protein kinase 20 CPK20 \\
\hline CUST_25785_57840 & VIT_18s0001g00980 & GSVIVT01008747001 & - & -0.61 & $7.21 \mathrm{E}-03$ & Calcium-dependent protein kinase 9 CPK9 \\
\hline CUST_45042_37341 & VIT_15s0021g01150 & GSVIVT01018316001 & AT1G28710 & -1.59 & $4.74 \mathrm{E}-07$ & Calcium-dependent protein kinase-related \\
\hline CUST_46046_19308 & VIT_01s0010g02150 & GSVIVT01010291001 & AT1G14590 & 1.08 & $3.25 \mathrm{E}-07$ & Calcium-dependent protein kinase-related \\
\hline CUST_25533_22696 & VIT_05s0020g04240 & GSVIVT01018059001 & AT5G57110 & 0.76 & $7.26 \mathrm{E}-04$ & Calcium ATPase 12 (ACA12) \\
\hline CUST_38995_37629 & VIT_14s0030g02090 & GSVIVT01021803001 & AT3G63380 & 1.41 & $2.60 \mathrm{E}-05$ & Calcium ATPase 12 (ACA12) \\
\hline CUST_40093_46251 & VIT_05s0020g04260 & GSVIVT01018061001 & AT3G22910 & -0.63 & $9.81 \mathrm{E}-03$ & Calcium ATPase 13 (ACA13) \\
\hline NG2_7370_1539 & VIT_09s0018g01840 & GSVIVT01016118001 & AT3G13320 & 0.99 & 1.10E-05 & Cation exchanger (CAX2) \\
\hline CUST_43832_58554 & VIT_08s0056g01480 & GSVIVT01029961001 & AT5G17860 & 0.97 & 4.47E-03 & Cation exchanger (CAX7) \\
\hline NG11_49713_18843 & VIT_14s0068g02190 & GSVIVT01033108001 & AT3G27170 & -0.61 & 7.55E-05 & Chloride channel B (CLC-b) \\
\hline NG11_46088_11883 & VIT_19s0015g01850 & GSVIVT01014852001 & AT1G55620 & 1.37 & $2.85 E-34$ & Chloride channel F (CLC-f) \\
\hline NG11_51750_10097 & VIT_06s0004g03520 & GSVIVT01025107001 & AT3G45650 & 1.27 & $7.60 \mathrm{E}-19$ & Nitrate excretion transporter 1 \\
\hline NG11_44542_25973 & VIT_06s0004g03530 & GSVIVT01025106001 & AT3G45650 & 1.61 & $1.24 \mathrm{E}-32$ & Nitrate excretion transporter 2 \\
\hline NG11_46422_21127 & VIT_11s0016g05170 & GSVIVT01015522001 & AT2G26690 & -1.22 & $2.58 \mathrm{E}-19$ & Nitrate transporter 1.4 \\
\hline CUST_37073_22417 & VIT_01s0127g00070 & GSVIVT01013802001 & AT1G12940 & 0.63 & $6.29 \mathrm{E}-03$ & Nitrate transporter 2.5 \\
\hline CUST_42271_1540 & VIT_14s0066g00850 & GSVIVT01032430001 & AT5G14570 & 1.59 & $8.82 \mathrm{E}-06$ & Nitrate transporter 2.7 \\
\hline NG2_12101_30038 & VIT_03s0097g00510 & GSVIVT01038513001 & AT5G64410 & 0.87 & $1.65 \mathrm{E}-06$ & Oligopeptide transporter OPT4 \\
\hline NG12_21396_16431 & VIT_12s0035g01820 & GSVIVT01023146001 & AT1G59740 & 0.52 & $2.47 \mathrm{E}-05$ & $\begin{array}{l}\text { Proton-dependent oligopeptide transport } \\
\text { (POT) family protein }\end{array}$ \\
\hline NG11_4749_12704 & VIT_17s0000g05550 & GSVIVT01008072001 & AT3G47960 & 0.54 & $1.88 \mathrm{E}-04$ & Glucosinolate transporter 1 (GTR1) \\
\hline NG11_7897_10153 & VIT_14s0066g02020 & GSVIVT01032550001 & AT5G14940 & 0.64 & $3.31 \mathrm{E}-07$ & $\begin{array}{l}\text { Proton-dependent oligopeptide transport } \\
\text { (POT) family protein }\end{array}$ \\
\hline NG11_35177_1429 & VIT_18s0041g00670 & GSVIVT01026058001 & AT1G72140 & 0.89 & $7.91 \mathrm{E}-14$ & $\begin{array}{l}\text { Proton-dependent oligopeptide transport } \\
\text { (POT) family protein }\end{array}$ \\
\hline NG11_25530_14040 & VIT_04s0008g03580 & GSVIVT01035643001 & AT1G22550 & 1.11 & $2.21 \mathrm{E}-24$ & Nitrate transporter 1.11 \\
\hline NG11_31776_20297 & VIT_16s0050g01860 & GSVIVT01028789001 & AT5G24030 & 0.54 & $4.61 \mathrm{E}-05$ & SLAH3 (SLAC1 Homologue 3) \\
\hline CUST_21950_56777 & VIT_07s0191g00070 & GSVIVT01003419001 & AT4G40010 & -1.01 & $1.28 \mathrm{E}-04$ & SNF1-related protein kinase 2.7 (SnRK2.7) \\
\hline CUST_41758_42394 & VIT_00s0710g00020 & GSVIVT01002389001 & AT4G33950 & -0.56 & $1.54 \mathrm{E}-02$ & SNF1-related protein kinase 2.6 (SnRK2.6) \\
\hline CUST_27252_1533 & VIT_01s0011g06550 & GSVIVT01011573001 & AT2G01980 & -2.30 & $1.53 \mathrm{E}-05$ & SOS1 ( $\mathrm{Na}+/ \mathrm{H}+$ antiporter $)$ \\
\hline CUST_15165_41173 & VIT_06s0004g07830 & GSVIVT01024587001 & AT5G58380 & -0.73 & $1.72 \mathrm{E}-06$ & SOS2 (salt overly sensitive 2 ) \\
\hline CUST_27642_7432 & VIT_16s0098g01870 & GSVIVT01038549001 & AT5G24270 & -0.67 & $8.65 E-03$ & SOS3 (salt overly sensitive 3 ) \\
\hline
\end{tabular}

List of significantly differentially expressed genes $(P<0.05, \geq \pm 1.41$ fold) between the contrasting grapevine rootstocks 140 Ruggeri and K51-40 in the absence of $\mathrm{Cl}^{-}$treatment that have putative roles in ion homeostasis. Positive log(2) FC values = higher in 140 Ruggeri. 
Table 2 Highly significantly differentially expressed genes between contrasting rootstocks under control conditions

\begin{tabular}{|c|c|c|c|c|c|c|c|}
\hline Probe ID & $12 \times V 1$ blast hit & $12 x V 0$ gene ID & $\begin{array}{l}\text { Arabidopsis } \\
\text { homolog }\end{array}$ & $\begin{array}{l}\log 2 \mathrm{FC} \\
140 \mathrm{R}- \\
\mathrm{K} 51-40\end{array}$ & p-value & B & Functional annotation \\
\hline NG11_47168_24630 & VIT_09s0002g02430 & GSVIVT01016879001 & AT3G21250 & -1.90 & $1.69 \mathrm{E}-42$ & 89.62 & $\mathrm{ABC}$ transporter $\mathrm{C}$ member 12 \\
\hline NG11_46088_11883 & VIT_19s0015g01850 & GSVIVT01014852001 & AT1G55620 & 1.37 & $2.85 \mathrm{E}-34$ & 70.44 & CLCf (chloride channel F) \\
\hline NG11_44542_25973 & VIT_06s0004g03530 & GSVIVT01025106001 & AT3G45650 & 1.61 & $1.24 \mathrm{E}-32$ & 66.55 & Nitrate excretion transporter 2 \\
\hline NG2_21308_18913 & VIT_11s0016g02570 & GSVIVT01015240001 & AT2G19690 & 3.01 & $1.05 \mathrm{E}-26$ & 56.42 & Phospholipase A2 precursor \\
\hline NG2_12381_40127 & VIT_06s0004g06340 & GSVIVT01024768001 & AT5G58800 & 3.35 & $5.46 \mathrm{E}-26$ & 54.67 & Flavodoxin-like quinone reductase 1 \\
\hline NG2_21123_37199 & VIT_12s0028g02740 & GSVIVT01020642001 & - & -4.06 & $1.36 \mathrm{E}-24$ & 51.28 & $\begin{array}{l}\text { Isoflavone methyltransferase/Orcinol } \\
\text { O-methyltransferase } 1 \text { oomt1 }\end{array}$ \\
\hline NG11_25530_14040 & VIT_04s0008g03580 & GSVIVT01035643001 & - & 1.11 & $2.21 \mathrm{E}-24$ & 47.44 & Nitrate transporter 1.11 \\
\hline NG2_12165_35517 & VIT_13s0073g00250 & GSVIVT01034634001 & AT2G26230 & -5.07 & 9.34E-23 & 46.84 & Urate oxidase \\
\hline NG2_48691_28703 & VIT_15s0046g01950 & GSVIVT01026987001 & - & 2.97 & 4.01E-22 & 45.28 & Anthocyanidine rhamnosyl-transferase \\
\hline NG2_28672_23579 & VIT_10s0003g03780 & GSVIVT01021513001 & AT1G30130 & 2.18 & $7.23 \mathrm{E}-22$ & 44.65 & Unknown protein \\
\hline NG2_35994_23405 & VIT_18s0001g13850 & GSVIVT01009855001 & AT4G31500 & -3.20 & $1.93 \mathrm{E}-21$ & 43.62 & $\begin{array}{l}\text { Cytochrome P450, family } 83, \\
\text { subfamily B, polypeptide } 1\end{array}$ \\
\hline NG2_48494_21157 & VIT_18s0001g13820 & GSVIVT01009854001 & AT4G31500 & -3.32 & $1.78 \mathrm{E}-19$ & 38.90 & $\begin{array}{l}\text { Cytochrome P450, family 83, } \\
\text { subfamily B, polypeptide } 1\end{array}$ \\
\hline NG2_5431_23220 & VIT_00s0153g00040 & GSVIVT01001251001 & - & -2.73 & $1.90 \mathrm{E}-19$ & 38.83 & S-locus receptor kinase \\
\hline NG2_48249_3223 & VIT_03s0038g01760 & GSVIVT01024088001 & - & 3.48 & $2.76 \mathrm{E}-19$ & 38.44 & Disease resistance protein (CC-NBS class) \\
\hline NG2_33320_2332 & VIT_08s0007g01590 & GSVIVT01034034001 & - & -1.80 & $5.70 \mathrm{E}-19$ & 37.65 & Fructose 1,6-bisphosphatase \\
\hline NG2_21199_29690 & VIT_06s0004g00730 & GSVIVT01025431001 & AT3G13550 & 2.00 & 8.19E-19 & 37.26 & Ubiquitin-conjugating enzyme E2 D/E \\
\hline NG2_11819_5360 & VIT_05s0094g00120 & GSVIVT01038099001 & AT3G59600 & 2.61 & $3.10 \mathrm{E}-18$ & 35.84 & $\begin{array}{l}\text { DNA-directed RNA polymerase II } \\
\text { subunit } \mathrm{H}\end{array}$ \\
\hline NG11_46422_21127 & VIT_11s0016g05170 & GSVIVT01015522001 & AT2G26690 & -1.22 & $2.58 \mathrm{E}-19$ & 35.59 & Nitrate transporter 1.4 \\
\hline NG2_12023_10427 & VIT_18s0001g05430 & GSVIVT01036371001 & - & 3.07 & 4.99E-18 & 35.33 & (+)-delta-cadinene synthase isozyme XC14 \\
\hline NG2_45557_29139 & VIT_10s0042g01130 & GSVIVT01026257001 & AT4G19670 & 3.69 & 7.83E-18 & 34.85 & Zinc finger (C3HC4-type ring finger) \\
\hline NG2_40716_2133 & VIT_06s0061g00120 & GSVIVT01031543001 & - & 3.17 & 7.99E-18 & 34.82 & Beta-1,3-glucanase [Vitis riparia] \\
\hline NG11_51750_10097 & VIT_06s0004g03520 & GSVIVT01025107001 & AT3G45650 & 1.27 & 7.60E-19 & 34.49 & Nitrate excretion transporter 1 \\
\hline NG2_45497_36221 & VIT_12s0028g02810 & GSVIVT01020636001 & - & -1.58 & $2.64 \mathrm{E}-17$ & 33.55 & $\begin{array}{l}\text { Isoflavone methyltransferase/Orcinol } \\
\text { O-methyltransferase } 1 \text { oomt1 }\end{array}$ \\
\hline NG2_6989_23958 & VIT_06s0004g05440 & GSVIVT01024878001 & AT2G29260 & -1.23 & $3.46 \mathrm{E}-17$ & 33.27 & Tropinone reductase \\
\hline NG2_5127_34182 & VIT_03s0097g00620 & GSVIVT01038529001 & AT5G64440 & 1.71 & 4.59E-17 & 32.98 & $\mathrm{~N}$-acylethanolamine amidohydrolase \\
\hline NG2_7581_45053 & VIT_06s0080g00800 & GSVIVT01036089001 & AT5G22360 & 2.01 & $7.43 \mathrm{E}-17$ & 32.47 & Vesicle-associated membrane protein 714 \\
\hline NG2_12628_32903 & VIT_10s0071g00440 & GSVIVT01034406001 & AT4G11900 & -3.24 & 7.90E-17 & 32.40 & $\begin{array}{l}\text { Serine/threonine-protein kinase } \\
\text { receptor ARK3 }\end{array}$ \\
\hline NG2_48742_21119 & VIT_08s0007g09030 & GSVIVT01033230001 & - & -1.40 & $2.03 \mathrm{E}-16$ & 31.39 & DnaJ homolog, subfamily A, member 5 \\
\hline NG2_575_20076 & VIT_16s0098g01670 & GSVIVT01038570001 & AT5G53070 & 1.57 & $3.23 \mathrm{E}-16$ & 30.90 & Ribosomal protein L9 \\
\hline NG2_5167_10137 & VIT_05s0029g00770 & GSVIVT01020981001 & - & -1.67 & 3.40E-16 & 30.84 & Nematode resistance-like protein \\
\hline NG2_12777_24696 & VIT_18s0117g00080 & GSVIVT01012796001 & AT5G36930 & 3.34 & $3.95 \mathrm{E}-16$ & 30.68 & $\mathrm{R}$ protein $\mathrm{L} 6$ \\
\hline NG2_5559_11115 & VIT_02s0025g00930 & GSVIVT01019469001 & AT3G59140 & -1.63 & $5.03 \mathrm{E}-16$ & 30.43 & Multidrug resistance-associated protein 14 \\
\hline NG2_36555_51297 & VIT_03s0088g00390 & GSVIVT01037045001 & AT5G23590 & 1.34 & $6.02 \mathrm{E}-16$ & 30.24 & DnaJ homolog, subfamily C, member 17 \\
\hline
\end{tabular}

Highly significantly differentially expressed unique genes $(P<0.05, \geq \pm 1.41$ fold, $\mathrm{B}>30)$ between 140 Ruggeri and K51-40 root tissue under control conditions identified using the B-statistic. Positive $\log (2)$ FC values = higher in 140 Ruggeri.

(ALMT) [60]. ALMTs are a large multigene family with multiple roles; despite their name most ALMTs are not activated by aluminium and they allow the permeation of various anions. For example, ALMTs function in anion homeostasis and mineral nutrition, (ZmALMT1) [61], or $\mathrm{Cl}^{-}$transport across the tonoplast (AtALMT9) [62]. Root
ALMTs might therefore have a role in $\mathrm{Cl}^{-}$exclusion. Three ALMT1 homologs were differentially expressed between rootstocks (Table 1). Whether these proteins mediate $\mathrm{Cl}^{-}$fluxes, and the directionality of such fluxes, remains unresolved, but $\mathrm{Cl}^{-}$exclusion could arise through efflux of $\mathrm{Cl}^{-}$to the rhizosphere (higher expression in 140 


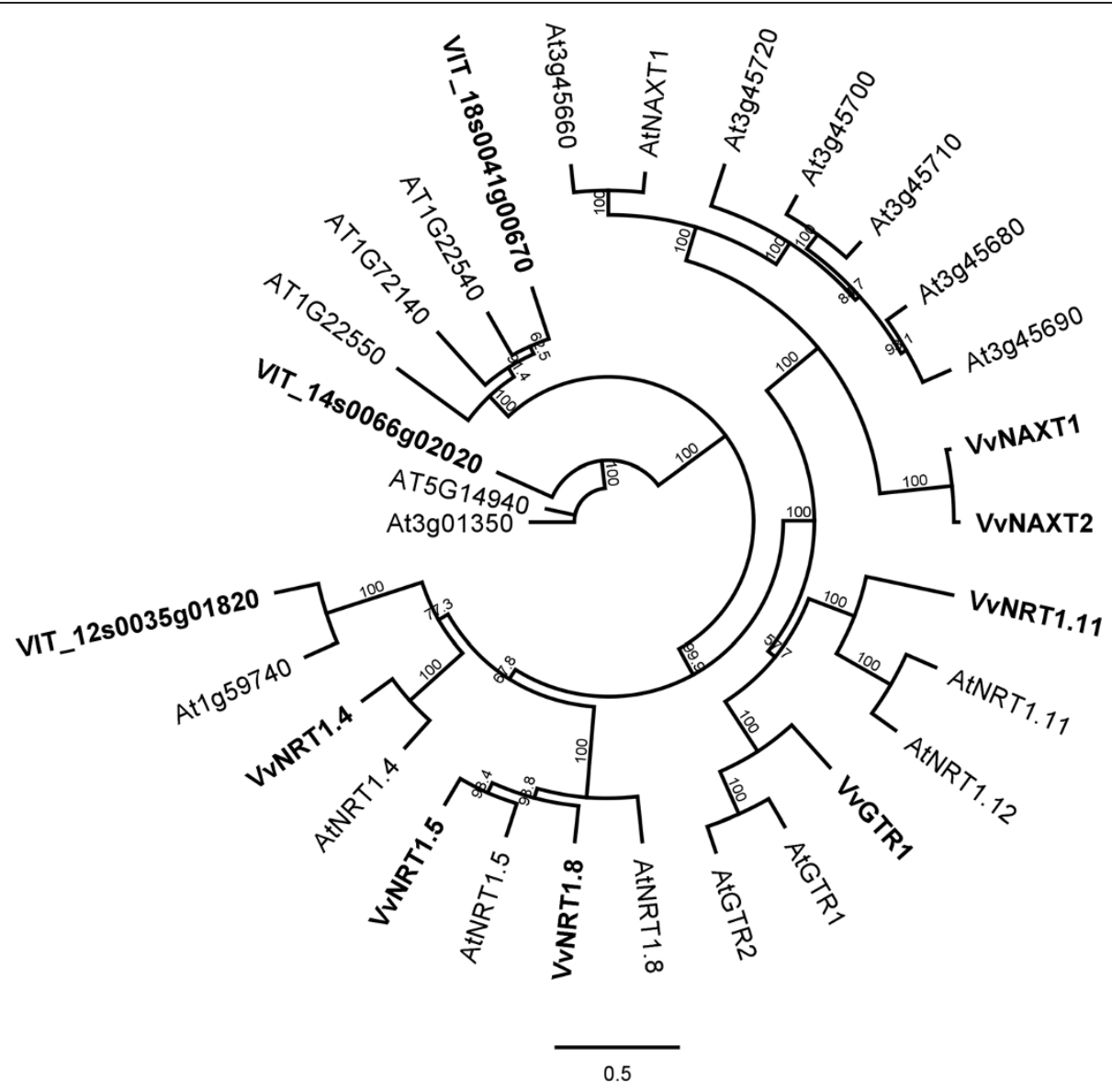

Figure 4 Phylogenetic relationship between Arabidopsis and grapevine NRT/POT gene family members. Unrooted neighbour-joining tree of Arabidopsis and grapevine (bold) NRT/POT family members with bootstrap values from 1000 iterations. Scale= substitutions per site. Gene identifiers for the protein sequences used are shown in Additional file 2, while the multiple sequence alignment is shown in Additional file 3.

Ruggeri, VIT_06s0009g00450,VIT_08s0105g00250) (Table 1) or reduced $\mathrm{Cl}^{-}$entry in the cortex and restricted xylem loading of $\mathrm{Cl}^{-}$(lower expression in 140 Ruggeri, VIT 06s0080g00170) (Table 1; Figure 6D and G).

\section{Calcium transporters (CAX and ACA)}

Calcium exchangers (CAX) mediate $\mathrm{Ca}^{2+} /$ cation antiport activity across the tonoplast. Roles of CAXs include cell specific storage of $\mathrm{Ca}^{2+}$ by CAX1 [63], while Arabidopsis cax3 mutants are sensitive to $\mathrm{NaCl}, \mathrm{LiCl}$ and acidic $\mathrm{pH}$, suggesting a possible role in salt tolerance [64]. Three grapevine $C A X$ transcripts were more abundant in roots of 140 Ruggeri compared to K51-40 (Table 1). In addition to CAX, the plant plasma and vacuolar membranes harbour auto-inhibited $\mathrm{Ca}^{2+}$-ATPases (ACA), of which Arabidopsis $A C A 4$ can improve salt tolerance of yeast [65]. Six $A C A$ s were differentially expressed between 140 Ruggeri and K51-40. These data indicate that genes regulating cytosolic free calcium $\left(\left[\mathrm{Ca}^{2+}\right]_{\mathrm{cyt}}\right)$ in roots could be important for grapevine $\mathrm{Cl}^{-}$exclusion.
CLC

Two CLCs showed differential expression between rootstocks under control conditions. A gene homologous to Arabidopsis AtCLCb (VIT_14s0068g02190) was less abundant in 140 Ruggeri (Table 1). Another CLC with homology to AtCLCf (VIT_19s0015g01850) was less abundant in K51-40 (Table 1). Differential expression of $V v C L C f$ was also identified as highly statistically significant (Table 2).

\section{SLAH3 and ABA signalling}

Homologs of the Arabidopsis SLAC1 anion channel (AtSLAH1 and AtSLAH3) are plasma membrane localized, expressed in the root vasculature, and functionally complement guard cell anion efflux in the slac1 mutant [23]. This indicates that SLAHs might be involved in anion homeostasis [23] and loading to the xylem sap [54]. $V v S L A H 3$ was more abundant in the $\mathrm{Cl}^{-}$excluder 140 Ruggeri compared to K51-40 under control conditions (Table 1; Figure 6E). This contrasts with Citrus, where CCSLAH1 was up-regulated by $90 \mathrm{mM}$ salt stress 


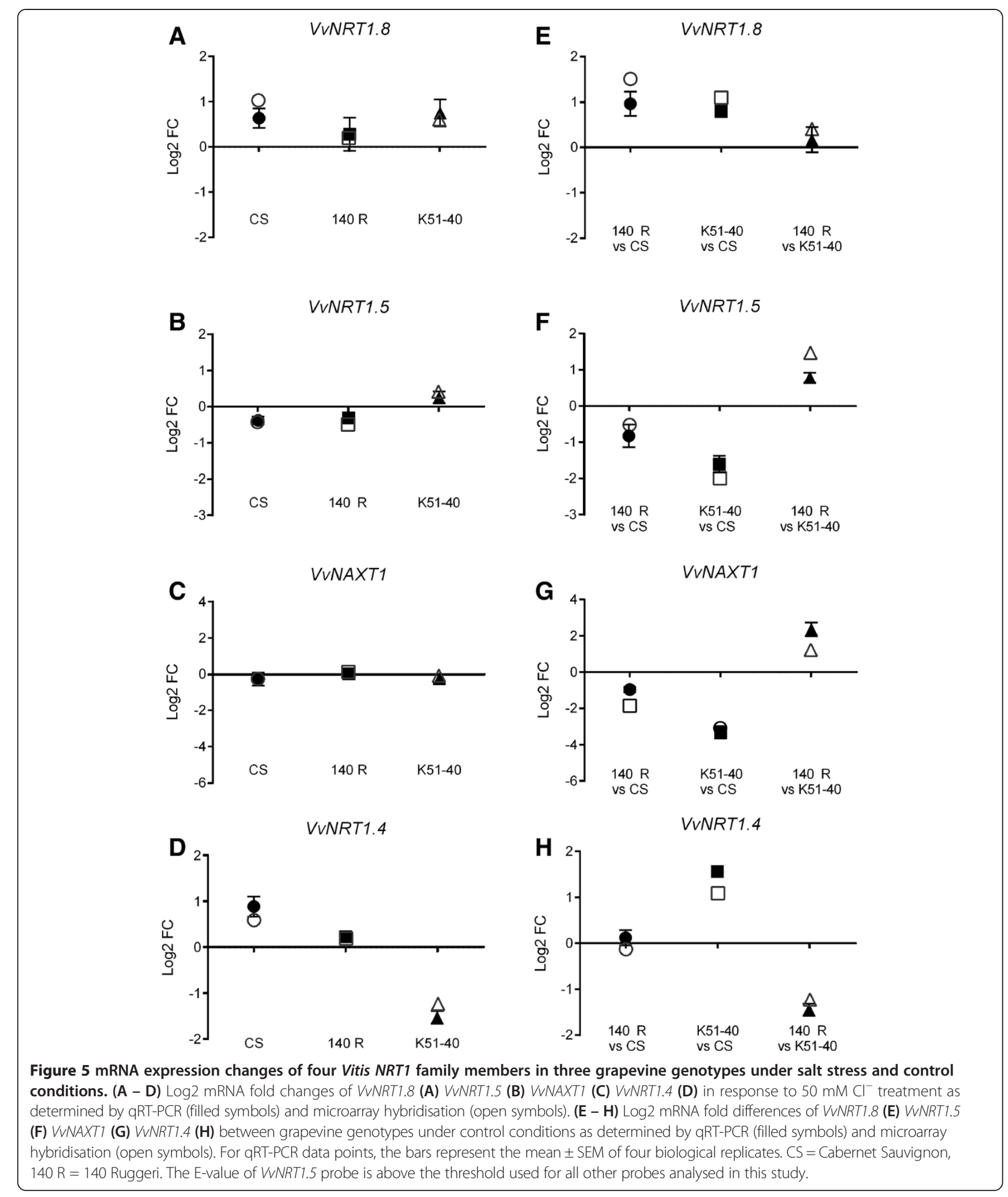

in a $\mathrm{Cl}^{-}$accumulating rootstock [22]. Reconstitution in $X$. laevis oocytes has demonstrated that plant SLAC/ SLAH activity is tightly regulated by kinase/phosphatase activity following an ABA signal [66]. Homologs of the
Arabidopsis ABA signalling machinery were differentially expressed between rootstocks. The ABA receptor VvPYL1/RCAR11 was more highly expressed in 140 Ruggeri (Table 1). Two SNF1-related protein kinase 2 

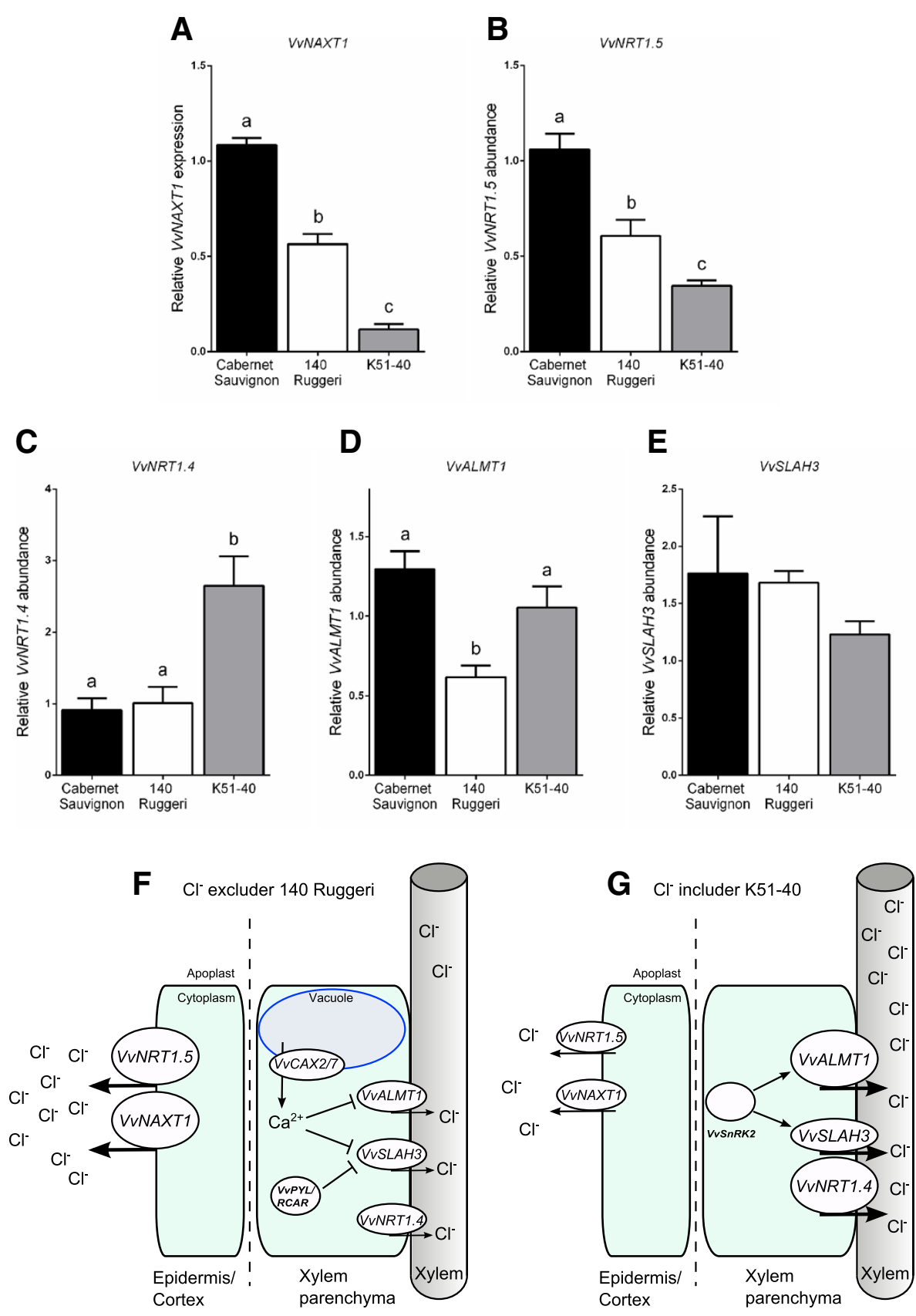

Figure 6 Relative transcript abundances of membrane proteins in roots of grapevine genotypes under control conditions measured by qRT-PCR, and a model indicating possible molecular mechanisms for reduced net xylem loading of $\mathrm{Cl}^{-}$in 140 Ruggeri. (A - B) relative expression levels of VVNAXT1 (A) and VVNRT1.5 (B) measured by qRT-PCR, which represent possible avenues for cortical or epidermal efflux of $\mathrm{Cl}^{-}$ out of roots. (C - E) relative expression levels of VVNRT1.4 (C), VVALMT1 (D) and VVSLAH3 (E) measured by qRT-PCR, which represent possible avenues for xylem loading of $\mathrm{Cl}^{-}$. Bars represent the mean of four biological replicates $\pm \mathrm{SEM}$. Transcript abundance is relative to the Cabernet Sauvignon biological replicate with the lowest cycle threshold $(\mathrm{Ct})$ value, which was set to 1 . Statistical differences were determined using one way ANOVA with Holm-Sidak's multiple comparisons test to compare the means. ( $\mathbf{F}-\mathbf{G})$ proposed model for reduced net xylem loading of $\mathrm{Cl}^{-}$in 140 Ruggeri relative to K51-40. (F) In 140 Ruggeri, anion efflux from cortical or epidermal root cells could be mediated through putative anion channels VVNRT1.5 and VVNAXT1 which are transcriptionally more abundant in the $\mathrm{Cl}^{-}$excluder. Xylem loading of $\mathrm{Cl}^{-}$could be restricted through reduced VVNRT1.4 abundance, or inhibition of VVSLAH3 and VVALMT by higher $\left[\mathrm{Ca}^{2+}\right]_{\mathrm{cyt}}$ mediated by VVCAX3 (directly, or in partnership with $\mathrm{Ca}^{2+}$ dependent protein kinases). (G) In K51-40, anion efflux to the xylem apoplast could be enhanced through increased abundance of VVALMT1 and VVNRT1.4, and activation of VVALMT1 and VVSLAH3 by SnRK2 kinases. 
(SnRK2) family members including the Vitis ortholog of SnRK2.6 (open stomata 1 (OST1)) were repressed in 140 Ruggeri, and multiple calcium dependent protein kinases $(C P K)$ were differentially expressed between rootstocks (Table 1). Homologs of these genes in other plants have proven roles in ABA induced activation of SLAC1 in guard cells [67] and might be involved in SLAH3 regulation in Vitis roots.

\section{Other candidates}

Two ABC transporters were significantly differentially expressed between rootstocks; a C-type (ABCC 12) (VIT 09s0002g02430) (higher in 140 Ruggeri) and multidrug resistance 12-type (VIT_02s0025g00930) (higher in K5140) (Table 2). A role in $\mathrm{Cl}^{-}$transport has not been identified for $\mathrm{ABC}$ transporters in plants, although reports suggest roles in arsenic tolerance [68] and salt tolerance [69]. A C3HC4-type ring finger protein was more abundant in the tolerant variety 140 Ruggeri (Table 2). A $\mathrm{C} 3 \mathrm{HC} 4$ protein was potentially crucial for abiotic stress tolerance in rice roots [70]. A phospholipase A2 precursor (VIT_11s0016g02570) was also expressed alternatively between rootstocks (Table 2 ). The product of a phospholipase $\mathrm{A} 2$ activates a tonoplast $\mathrm{H}^{+} / \mathrm{Na}^{+}$antiporter in cultured cells of California poppy [71].

\section{Discussion}

Shoot chloride exclusion is one of several traits that underpins salt tolerance. However, the root-localised anion transport proteins (or their regulators) thought to be crucial for salt tolerance remain unidentified $[9,15,16,22]$. We therefore analysed the genome wide transcriptional response of grapevine roots to $\mathrm{Cl}^{-}$stress. Cabernet Sauvignon repressed transcripts encoding respiratory proteins, probably to reduce ROS production under salt stress. Although ROS may act as signalling molecules in eukaryotes [72,73], it has previously been reported that ROS production in grapevine cells that contrast in salttolerance represents a manifestation of cellular damage rather than an adaptive response [74]. We therefore propose a hierarchy exists in the magnitude of transcriptional responses to $\mathrm{Cl}^{-}$stress (K5140>> Cabernet Sauvignon> > 140 Ruggeri) that correlates with the amount of damage in the laminae. However, these differences in varietal responses to stress do not explain differential $\mathrm{Cl}^{-}$exclusion, which was statistically significant before salt stress (Figure 1).

Studies indicate that there is natural variation in the ability to tolerate salt stress in various plant species including Citrus [22], rice [70], barley [75,76], and Arabidopsis [77]. Our data support the hypothesis that $\mathrm{Cl}^{-}$exclusion in grapevine is mediated by anion transporters or channels that are differentially expressed between non-stressed 140 Ruggeri and K51-40. To this end, we have proposed a testable model for $\mathrm{Cl}^{-}$exclusion based on the expression levels of candidate genes identified in our study (Figure 6). These candidate genes for $\mathrm{Cl}^{-}$exclusion are subsequently discussed in the context of this model and existing literature.

In plant roots, anion movement across the plasma membrane of xylem parenchyma cells for loading to xylem vessels occurs through unidentified anion channels with fast and slow activation kinetics (X-QUAC and X-SLAC respectively) [17]. Anion conductances in Arabidopsis guard cells with homologous activation kinetics have been characterised, and the channels eliciting these currents identified. The slowly activating anion conductance in guard cells has been attributed to AtSLAC1 and AtSLAH3 channels [24,78], while guard cell QUAC is mediated by AtALMT12 [79]. It is therefore feasible that X-SLAC and X-QUAC arise from SLAH and ALMT channels in root cells. We identified $V v S L A H 3$ and three $V v A L M T 1$ transcripts that were expressed differently between rootstocks. Thermodynamics predicts that the loading of $\mathrm{Cl}^{-}$into the xylem under low apoplastic $\left[\mathrm{Cl}^{-}\right]$occurs by passive transport [80]. Therefore, transcripts that encode putative anion transport proteins with a high abundance in K51-40 are good candidates for controlling xylem loading of $\mathrm{Cl}^{-}$. Our results suggest that VvALMT1 may be involved in xylem loading of $\mathrm{Cl}^{-}$(Figure 6D and G). VvSLAH3 transcript was more abundant in 140 Ruggeri (Table 1; Figure $6 \mathrm{E}$ ). For it to be involved in xylem loading of $\mathrm{Cl}^{-}$ there are two alternatives. Arabidopsis SLAH3 has been shown to be much more permeable for $\mathrm{NO}_{3}^{-}$than $\mathrm{Cl}^{-}$ [78]. If this is the case in grapevine, the pathway for anion transport in 140 Ruggeri could be more $\mathrm{NO}_{3}{ }^{-}$selective than in K51-40, thus resulting in greater discrimination against $\mathrm{Cl}^{-}$loading of the xylem in 140 Ruggeri. Alternatively, SLAH3 could be permeable to $\mathrm{Cl}^{-}$but the extent of post-translational control differs between varieties, as elaborated below.

Cellular anion conductance must be tightly regulated to avoid uncontrolled electrolyte efflux [54], and for this reason complex signalling networks exist in plants. Upon an ABA induced rise in $\left[\mathrm{Ca}^{2+}\right]_{\text {cyt }}$, guard cell SLAC may be activated by calcium dependent protein kinases CPK23 and CPK21 [67]. Alternatively, the $\mathrm{Ca}^{2+}$ independent kinase SnRK2.6 (OST1) can activate both guard cell SLAC and QUAC in response to ABA [81]. In contrast, opposite regulation by $\mathrm{ABA}$ and $\left[\mathrm{Ca}^{2+}\right]_{\text {cyt }}$ occurs in root cells, with X-QUAC being inhibited by ABA and by high $\left[\mathrm{Ca}^{2+}\right]_{\text {cyt }}[17,19]$; whether kinases are involved in this regulation have not yet been determined. A transcript encoding the $V v P Y L 1 / R C A R 11$ ABA receptor was significantly more abundant in roots of 140 Ruggeri compared to $\mathrm{K} 51-40$. The $\mathrm{Cl}^{-}$excluder might therefore be more sensitive to $\mathrm{ABA}$, or may be primed for any 
slight increase in ABA concentration. Differential expression of vacuolar $C A X S$ and $A C A s$ between rootstocks might function to maintain $\left[\mathrm{Ca}^{2+}\right]_{\mathrm{cyt}}$ signals in root cells of 140 Ruggeri, thus participating in the $\mathrm{Ca}^{2+}$ dependent down-regulation of X-QUAC and X-SLAC (Figure 6F). AtCPK20 interacts with AtSLAH3 in Arabidopsis pollen tubes [82]. Differential expression of $V \nu C P K 20$, among other CPKs, between rootstocks might indicate an involvement of these kinases in VvSLAH3 regulation. In addition, differential expression of $V v S n R K 2.6$ and $V v S n R K 2.7$ between rootstocks implicates both the $\mathrm{Ca}^{2+}$ dependent and independent ABA signalling machinery in grapevine roots as possible mediators of $\mathrm{Cl}^{-}$exclusion (Figure 6G). The sheer number of genes potentially involved in X-QUAC and X-SLAC mediated pathways, possible kinase redundancy or multiple kinase targets, could explain the observations that $\mathrm{Cl}^{-}$exclusion in grapevine is polygenic $[15,83]$.

Arabidopsis has 53 NRT1 genes and rice has 80 NRT1 members. This has led to the question [55]: are there unidentified anionic substrates for NRTs beyond just nitrate or peptides to account for such large gene families? The large number of NRT1 genes identified in our screen suggests they might play some key role in $\mathrm{Cl}^{-}$ homeostasis. Plasma membrane localisation of plant NRTs heightens the possibility for roles in cellular $\mathrm{Cl}^{-}$ fluxes. However, the anion selectivities of plant NRTs have been rarely examined [9]. AtNAXT1 was shown not to transport $\mathrm{Cl}^{-}$[59], but characterisation of the remaining 6 Arabidopsis NAXTs is yet to be reported. If permeable to $\mathrm{Cl}^{-}$, greater abundance of $V v N A X T 1$ and VvNAXT2 in 140 Ruggeri compared to K51-40 (Table 1; Table 2; Figure 6A) could allow the $\mathrm{Cl}^{-}$excluding rootstock to excrete $\mathrm{Cl}^{-}$back to the external medium instead of transporting it to the shoot (Figure 6F). This function might be enhanced under salinity stress if cytosolic $\mathrm{pH}$ is reduced, as AtNAXT1 actively excretes anions under acid load, possibly to balance proton extrusion by $\mathrm{H}^{+}$ATPases [59]. This cannot work as the sole mechanism of $\mathrm{Cl}^{-}$exclusion, as 140 Ruggeri still retains more $\mathrm{Cl}^{-}$in the roots compared to Cabernet Sauvignon and K51-40 (Figure 1A). Other stress responsive plant NRT1s (VvNRT1.8, VvNRT1.5) showed similar expression profiles to orthologous genes in Arabidopsis. However, $V v N R T 1.5$ was less abundant in the root stele compared to the cortex (Additional file 13), indicating that this gene is more likely to be involved in cortical efflux of $\mathrm{Cl}^{-}$rather than $\mathrm{Cl}^{-}$ loading to the xylem (Figure $6 \mathrm{~F}$ and $\mathrm{G}$ ). Excessive $\mathrm{Cl}^{-}$in the root zone or cytoplasm could inhibit $\mathrm{NO}_{3}^{-}$transport (both uptake and efflux) due to the well-documented antagonism between these anions $[84,85]$. Therefore, differences in NRT1 expression in salt stressed grapevine roots also could be a compensatory mechanism to overcome this ionic antagonism.
Multiple studies have linked plant CLCs to salt tolerance [86-89]. $V \nu C L C b$ and $V \nu C L C f$ were expressed differently between rootstocks under control conditions. In Arabidopsis, $A t C L C b$ is a vacuolar $\mathrm{NO}_{3}^{-} / \mathrm{H}^{+}$exchanger [90], as is AtCLCa [91]. A single missense mutation in AtCLCa changes the selectivity from $\mathrm{NO}_{3}^{-}$to $\mathrm{Cl}^{-}[92,93]$. It is therefore possible that $V v C L C b$ in Vitis roots participates in $\mathrm{Cl}^{-}$sequestration in cell vacuoles, although greater expression in K51-40 does not fully support this. AtCLCf is associated with the trans-Golgi network [94], so a role in salt tolerance is less likely. Further study into Vitis CLCs is therefore needed before concluding a role in grapevine salt tolerance.

Candidate genes for plant $\mathrm{Cl}^{-}$exclusion identified by Brumos et al. [22] were not highlighted in our study. Our array design had two probes for the putative $\mathrm{Cl}^{-}$ conductance regulator VvICln (VIT_16s0022g01560) and neither were salt responsive, consistent with short-term stress response in Citrus but contrasting with the longterm results [22]. On the other hand, one probe showed statistically significant differential expression between varieties under control conditions but was greater in the $\mathrm{Cl}^{-}$excluding rootstock (data not shown). This means if $V v I C l n$ contributes to $\mathrm{Cl}^{-}$exclusion in 140 Ruggeri, it must act as a negative regulator of $\mathrm{Cl}^{-}$conductance. This seems unlikely given data in animals and plants [22,26]. $V v C C C$ and $V v S L A H 1$ were also not differentially expressed, and so if they are involved may be regulated at the post-translational level, which cannot be highlighted by microarray technology. Indeed the activity of many plant anion channels is modified by phosphorylation events such as AtNRT1.1 [95], AtSLAC1 [96] and AtCLCa [97]. Differences in expression of SLAC/SLAH regulators $S n R K 2$ and $C P K$ between rootstocks ensures $V v S L A H 1$ remains a candidate for $\mathrm{Cl}^{-}$homeostasis in Vitis. In future studies, it would be valuable to identify interacting partners of the protein kinases identified as differentially expressed in this study, and any functional changes induced by such interactions.

\section{Conclusions}

Using a whole root transcriptome approach, a detailed analysis of root mRNA profiles of contrasting grapevine genotypes is presented. This provides a complement to earlier physiological studies of the same varieties that have demonstrated the mechanism of shoot $\mathrm{Cl}^{-}$exclusion as the restriction of its net xylem loading at the root $[15,16,98]$. A valuable list of candidate genes likely to mediate shoot $\mathrm{Cl}^{-}$exclusion has been identified. Future functional characterisation of these genes, including the elucidation of protein-protein interactions, may enable their use in grapevine rootstock breeding efforts. More broadly the further study of these genes and their 
homologs in other species will aid our understanding of long distance $\mathrm{Cl}^{-}$transport in plants.

\section{Availability of supporting data}

Data supporting the results of this article are available in the Gene Expression Omnibus repository (http://www.ncbi. nlm.nih.gov/geo/) under accession number GSE57770. An ArrayQualityMetrics report is available at http://dx.doi. org/10.6070/H4CZ354H.

\section{Additional files}

Additional file 1: List of 90 predicted $V$. vinifera genes encoding putative anion transporters, and their predicted functional annotation, that were spotted onto the custom Agilent microarray slides multiple times for B-statistic analysis.

Additional file 2: Gene identifiers and annotations of the amino acid sequences used in the phylogenetic analysis of interesting NRT1 members.

Additional file 3: Multiple sequence alignment of Arabidopsis and grapevine NRT members for the data presented in Figure 4. Shading is representative of the Blosum62 score matrix as follows: black (100\% similar) dark grey ( $80 \%$ similar) light grey $(60 \%$ similar) unshaded $(<60 \%$ similar).

Additional file 4: List of primers used in this study.

Additional file 5: Correlation between expression ratios determined by Agilent custom gene expression array and qRT-PCR. (a) Gene expression ratios of control to salt treated samples were compared for 12 genes (VIT_00s0229g00130, VIT_0150011g06550, VIT_02s0012g01160, VIT_06s0004g03520, VIT_06s0080g00170, VIT_08s0040g01890, VIT_08s0040g03220, VIT_11s0016g05170, VIT_13s0019g00330, VIT_1450108g00700, VIT_15s0021900330, VIT_1650050g01860) in all 3 grapevine varieties by microarray and qRT-PCR. (b) Gene expression ratios of varietal differences under control conditions were compared for 12 genes (VIT_01s0011g06550, VIT_02s0012g01160, VIT_0650004g03520, VIT_06s0080g00170, VIT_08s0040g01890, VIT_08s0040g03220,

VIT_1150016g05170, VIT_1350019g00330, VIT_1450108g00700,

VIT_15s0021g00330, VIT_1650050g01860, VIT_17s0000g05550) and 3 grapevine cultivars as in (a). Linear regression analysis $R^{2}$ value shown inset. For qRT-PCR primers see Additional file 4. Gene expression levels obtained via GRT-PCR were normalised to the geometric mean of $V_{V A c t i n} V_{V E F T-a}$ and $V V U B Q-L 40$.

Additional file 6: List of 1361 differentially expressed $(P<0.05, \geq$ \pm 1.41 fold) unique transcripts in at least one Vitis spp. genotype under $50 \mathrm{mM} \mathrm{Cl}^{-}$treatment.

Additional file 7: Unique transcripts that were significantly up-regulated ( $P<0.05, \geq 1.41 \mathrm{fold}$ ) in 140 Ruggeri in response to 50 $\mathrm{mM} \mathrm{Cl}{ }^{-}$treatment and clustering together (cluster A, Figure 3).

Additional file 8: Unique transcripts that were significantly downregulated $(P<0.05, \leq-1.41$ fold $)$ in $\mathrm{K} 51-40$ in response to $50 \mathrm{mM}$ $\mathrm{Cl}^{-}$treatment and clustering together (cluster B, Figure 3).

Additional file 9: Unique transcripts that were significantly downregulated $(P<0.05, \leq-1.41$ fold) in Cabernet Sauvignon in response to $50 \mathrm{mM} \mathrm{Cl}^{-}$treatment and clustering together (cluster C, Figure 3).

Additional file 10: Transcripts encoding putative membrane transporters or channels that were significantly down-regulated $(P<0.05, \leq-1.41$ fold $)$ in 140 Ruggeri in response to $50 \mathrm{mM} \mathrm{Cl}^{-}$ treatment.

Additional file 11: List of 4527 unique transcripts that were significantly differentially expressed $(P<0.05, \geq \pm 1.41$ fold) between 140 Ruggeri and K51-40 under control conditions (non-salt).

Additional file 12: List of 214 unique transcripts encoding putative membrane transporters or channels that were significantly differentially expressed ( $P<0.05, \geq \pm 1.41$ fold) between 140 Ruggeri and K51-40 under control conditions (non-salt).

Additional file 13: VvNRT1.5 expression in different root tissues of grapevine. (a) Levels of VVNRT1.5 transcript in enriched fractions of the root cortex and stele of salt stressed $\left(50 \mathrm{mM} \mathrm{Cl}^{-}\right)$grapevine determined by qRT-PCR. Bars are SEM of 3 biological replicates. Asterisk represents significant difference in the stele compared to the cortex (Student's t-test, $P<0.05$ ). (b) Levels of VVPIP1.1 transcript in enriched fractions of the root cortex and stele of salt stressed $\left(50 \mathrm{mM} \mathrm{Cl}^{-}\right)$grapevine determined by qRT-PCR. Bars are SEM of 3 biological replicates. Asterisk represents significant difference in the stele compared to the cortex (Student's t-test, $P<0.05$ ). VVPIP1.1 is known to be expressed in the root stele [99], and is therefore used as a control for adequate enrichment of stele and cortex root fractions in (a).

\section{Competing interests}

The authors declare that they have no competing interests.

\section{Authors' contributions}

SWH, ARW, RRW and MG contributed to project conception. SWH, ARW, RRW and DB harvested rooted leaves for expression studies. UB analysed the raw microarray data, performed microarray data normalization and performed the statistical analysis. DB propagated and maintained the plant material and performed ion content measurements. SWH performed all other analyses, drafted the initial manuscript and prepared the final version with MG. MG and RRW supervised the research. All authors read and approved the final manuscript.

\section{Acknowledgements}

The Authors thank Dr. Virginie Masson for help with data mining. Daniele Belluoccio is acknowledged for assistance with microarray chip design. We thank Dr. Haijun Gong for designing the primers for VVNAXT1. SWH was supported by an Australian Postgraduate Award and the Australian Grape and Wine Authority (GWR_PH1001). MG is supported by an Australian Research Council Future Fellowship (FT130100709). This research was funded by a Wine 2030 Research grant to SWH and also by Australia's grape growers and winemakers through their investment body, the Australian Grape and Wine Authority, with matching funds from the Australian Government (grant number (SP1002) awarded to RRW, ARW and MG.

\section{Author details}

${ }^{1}$ Australian Research Council Centre of Excellence in Plant Energy Biology, School of Agriculture, Food and Wine, \& Waite Research Institute, University of Adelaide, PMB1, Glen Osmond, South Australia 5064, Australia. ${ }^{2}$ Australian Centre for Plant Functional Genomics, South Australia 5064, Australia. ${ }^{3} \mathrm{CSIRO}$ Plant Industry, PO Box 350, Glen Osmond, South Australia 5064, Australia.

Received: 27 June 2014 Accepted: 3 October 2014

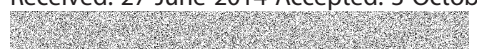

\section{References}

1. Maas EV, Hoffman GJ: Crop salt tolerance - current assessment. J Irrig Drain Div 1977, 103(2):115-134.

2. Downton WJS: Photosynthesis in salt-stressed grapevines. Aust J Plant Physiol 1977, 4(2):183-192.

3. Walker R, Blackmore D, Clingeleffer P, lacono F: Effect of salinity and Ramsey rootstock on ion concentrations and carbon dioxide assimilation in leaves of drip-irrigated, field-grown grapevines (Vitis vinifera L. Cv. Sultana). Aust J Grape Wine Res 1997, 3(2):66-74.

4. Ehlig CF: Effects of salinity on four varieties of table grapes grown in sand culture. Proceed Am Soc Horticultural Sci 1960, 76:323-331.

5. Walker RR, Blackmore DH, Clingeleffer PR, Correll RL: Rootstock effects on salt tolerance of irrigated field-grown grapevines (Vitis vinifera L. CV. Sultana). 1. Yield and vigour inter-relationships. Aust J Grape Wine Res 2002, 8(1):3-14.

6. Zhang XK, Walker RR, Stevens RM, Prior LD: Yield-salinity relationships of different grapevine (Vitis vinifera L.) scion-rootstock combinations. Aust J Grape Wine Res 2002, 8(3):150-156.

7. Walker RR, Blackmore DH, Clingeleffer PR: Impact of rootstock on yield and ion concentrations in petioles, juice and wine of Shiraz and Chardonnay 
in different viticultural environments with different irrigation water salinity. Aust J Grape Wine Res 2010, 16(1):243-257.

8. Walker RR, Blackmore DH, Clingeleffer PR, Correll RL: Rootstock effects on salt tolerance of irrigated field-grown grapevines (Vitis vinifera L. cv. Sultana) 2. Ion concentrations in leaves and juice. Aust I Grape Wine Res 2004, 10(2):90-99.

9. Teakle NL, Tyerman SD: Mechanisms of $\mathrm{Cl}^{-}$transport contributing to salt tolerance. Plant Cell Environ 2010, 33(4):566-589.

10. Apse MP, Aharon GS, Snedden WA, Blumwald E: Salt tolerance conferred by overexpression of a vacuolar $\mathrm{Na}^{+} / \mathrm{H}^{+}$antiport in Arabidopsis. Science 1999, 285(5431):1256-1258

11. Munns R, James RA, Xu B, Athman A, Conn SJ, Jordans C, Byrt CS, Hare RA, Tyerman SD, Tester M, Plett D, Gilliham M: Wheat grain yield on saline soils is improved by an ancestral $\mathrm{Na}^{+}$transporter gene. Nat Biotechnol 2012, 30(4):360-364.

12. Munns R, Tester M: Mechanisms of salinity tolerance. Annu Rev Plant Physiol Plant Mol Biol 2008, 59:651-681.

13. Shi H, Lee BH, WU SJ, Zhu JK: Overexpression of a plasma membrane $\mathrm{Na}^{+} / \mathrm{H}^{+}$antiporter gene improves salt tolerance in Arabidopsis thaliana. Nat Biotechnol 2003, 21(1):81-85.

14. Fort KP, Lowe KM, Thomas WA, Walker MA: Cultural conditions and propagule type influence relative chloride exclusion in grapevine rootstocks. Am J Enol Vitic 2013, 64(2):241-250.

15. Gong H, Blackmore D, Clingeleffer P, Sykes S, Jha D, Tester M, Walker R: Contrast in chloride exclusion between two grapevine genotypes and its variation in their hybrid progeny. J Exp Bot 2011, 62(3):989-999.

16. Tregeagle JM, Tisdall JM, Tester M, Walker RR: $\mathrm{Cl}^{-}$uptake, transport and accumulation in grapevine rootstocks of differing capacity for $\mathrm{Cl}^{-}$ exclusion. Funct Plant Biol 2010, 37(7):665-673.

17. Köhler B, Raschke $K$ : The delivery of salts to the xylem: three types of anion conductance in the plasmalemma of the xylem parenchyma of roots of barley. Plant Physiol 2000, 122(1):243-254

18. Cram WJ, Pitman MG: Action of abscisic acid on ion uptake and water flow in plant roots. Aust J Biol Sci 1972, 25(6):1125-1132.

19. Gilliham $M$, Tester $M$ : The regulation of anion loading to the maize root xylem. Plant Physiol 2005, 137(3):819-828.

20. Jia W, Wang Y, Zhang S, Zhang J: Salt-stress-induced ABA accumulation is more sensitively triggered in roots than in shoots. J Exp Bot 2002, 53(378):2201-2206

21. Brumos J, Colmenero-Flores JM, Conesa A, Izquierdo P, Sanchez G, Iglesias DJ, Lopez-Climent MF, Gomez-Cadenas A, Talon M: Membrane transporters and carbon metabolism implicated in chloride homeostasis differentiate salt stress responses in tolerant and sensitive Citrus rootstocks. Function Integrative Genom 2009, 9(3):293-309.

22. Brumos J, Talon M, Bouhlal RYM, Colmenero-Flores $\mathrm{JM}^{\mathrm{C}} \mathrm{Cl}^{-}$homeostasis in includer and excluder Citrus rootstocks: transport mechanisms and identification of candidate genes. Plant Cell Environ 2010, 33(12):2012-2027.

23. Negi J, Matsuda O, Nagasawa T, Oba Y, Takahashi H, Kawai-Yamada M, Uchimiya $\mathrm{H}$, Hashimoto M, lba K: $\mathrm{CO} 2$ regulator SLAC1 and its homologues are essential for anion homeostasis in plant cells. Nature 2008, 452(7186):483-U413.

24. Vahisalu T, Kollist H, Wang YF, Nishimura N, Chan WY, Valerio G, Lamminmaki A, Brosche M, Moldau H, Desikan R, Schroeder Jl, Kangasjarvi J: SLAC1 is required for plant guard cell S-type anion channel function in stomatal signalling. Nature 2008, 452(7186):487-491.

25. Colmenero-Flores JM, Martinez G, Gamba G, Vazquez N, Iglesias DJ, Brumos J, Talon M: Identification and functional characterization of cationchloride cotransporters in plants. Plant J 2007, 50(2):278-292.

26. Krapivinsky GB, Ackerman MJ, Gordon EA, Krapivinsky LD, Clapham DE: Molecular characterization of a swelling-induced chloride conductance regulatory protein, plCIn. Cell 1994, 76(3):439-448.

27. Jaillon O, Aury JM, Noel B, Policriti A, Clepet C, Casagrande A, Choisne N, Aubourg S, Vitulo N, Jubin C, Vezzi A, Legeai F, Huqueney P, Dasilva C, Horner D, Mica E, Jublot D, Poulain J, Bruyere C, Billault A, Segurens B, Gouyvenoux M, Ugarte E, Cattonaro F, Anthouard V, Vico V, Del Fabbro C, Alaux M, Di Gaspero G, Dumas V, et al: The grapevine genome sequence suggests ancestral hexaploidization in major angiosperm phyla. Nature 2007, 449(7161):463-U465.

28. Velasco R, Zharkikh A, Troggio M, Cartwright DA, Cestaro A, Pruss D, Pindo M, FitzGerald LM, Vezzulli S, Reid J, Malacarne G, Iliev D, Coppola G, Wardell B, Micheletti D, Macalma T, Facci M, Mitchell JT, Perazzolli M, Eldredge G, Gatto P, Oyzerski R, Moretto M, Gutin N, Stefanini M, Chen Y, Segala C,
Davenport C, Dematte L, Mraz A, et al: A high quality draft consensus sequence of the genome of a heterozygous grapevine variety. Plos One 2007, 2:12.

29. Grimplet J, Deluc LG, Tillett RL, Wheatley MD, Schlauch KA, Cramer GR, Cushman JC: Tissue-specific mRNA expression profiling in grape berry tissues. BMC Genomics 2007, 8:187.

30. Guillaumie S, Fouquet R, Kappel C, Camps C, Terrier N, Moncomble D, Dunlevy J, Davies C, Boss P, Delrot S: Transcriptional analysis of late ripening stages of grapevine berry. BMC Plant Biol 2011, 11(1):165.

31. Wang L, Li S, Wang J, Cramer G, Dai Z, Duan W, Xu H, Wu B, Fan P: Transcriptomic analysis of grape (Vitis vinifera $\mathrm{L}$.) leaves during and after recovery from heat stress. BMC Plant Biol 2012, 12(1):174.

32. Pontin M, Piccoli P, Francisco R, Bottini R, Martinez Zapater J, Lijavetzky D: Transcriptome changes in grapevine (Vitis vinifera L.) cv. Malbec leaves induced by ultraviolet-B radiation. BMC Plant Biol 2010, 10(1):224.

33. Fasoli M, Dal Santo S, Zenoni S, Tornielli GB, Farina L, Zamboni A, Porceddu A, Venturini L, Bicego M, Murino V, Ferrarini A, Delledonne M, Pezzotti M: The grapevine expression atlas reveals a deep transcriptome shift driving the entire plant into a maturation program. Plant Cell Online 2012, 24(9):3489-3505.

34. Tillett R, Ergul A, Albion R, Schlauch K, Cramer G, Cushman J: Identification of tissue-specific, abiotic stress-responsive gene expression patterns in wine grape (Vitis vinifera $\mathrm{L}$.) based on curation and mining of large-scale EST data sets. BMC Plant Biol 2011, 11(1):86.

35. Cramer GR, Ergul A, Grimplet J, Tillett RL, Tattersall EAR, Bohlman MC, Vincent D, Sonderegger J, Evans J, Osborne C, Quilici D, Schlauch KA, Schooley DA, Cushman JC: Water and salinity stress in grapevines: early and late changes in transcript and metabolite profiles. Function Integrative Genom 2007, 7(2):111-134.

36. Tattersall EAR, Grimplet J, Deluc L, Wheatley MD, Vincent D, Osborne C, Ergul A, Lomen E, Blank RR, Schlauch KA, Cushman JC, Cramer GR: Transcript abundance profiles reveal larger and more complex responses of grapevine to chilling compared to osmotic and salinity stress. Function Integrative Genom 2007, 7(4):317-333.

37. Schachtman DP, Thomas MR: A rapid method for generating sufficient amounts of uniform genotype-specific material from the woody perennial grapevine for ion transport studies. Plant Soil 2003, 253(1):195-199.

38. Hardiman G: Microarray platforms - comparisons and contrasts. Pharmacogenomics 2004, 5(5):487-502.

39. Grimplet J, Van Hemert J, Carbonell-Bejerano P, Diaz-Riquelme J, Dickerson J, Fennell A, Pezzotti M, Martinez-Zapater J: Comparative analysis of grapevine whole-genome gene predictions, functional annotation, categorization and integration of the predicted gene sequences. BMC Res Notes 2012, 5(1):213.

40. Johnson WE, Li C, Rabinovic A: Adjusting batch effects in microarray expression data using empirical Bayes methods. Biostatistics 2007, 8(1):118-127.

41. Kauffmann A, Gentleman R, Huber W: arrayQualityMetrics-a bioconductor package for quality assessment of microarray data. Bioinformatics 2009 25(3):415-416.

42. Smyth GK: Linear models and empirical bayes methods for assessing differential expression in microarray experiments. Stat Appl Genet Mol Biol 2004, 3. Article3.

43. Benjamini $Y$, Hochberg $Y$ : Controlling the false discovery rate: a practical and powerful approach to multiple testing. J R Stat Soc Ser B Methodol 1995, 57(1):289-300

44. Sturn A, Quackenbush J, Trajanoski Z: Genesis: cluster analysis of microarray data. Bioinformatics 2002, 18(1):207-208.

45. Du Z, Zhou X, Ling Y, Zhang Z, Su Z: agriGO: a GO analysis toolkit for the agricultural community. Nucleic Acids Res 2010, 38(Web Server):W64-W70.

46. Larkin MA, Blackshields G, Brown NP, Chenna R, McGettigan PA, McWilliam $H$, Valentin F, Wallace IM, Wilm A, Lopez R, Thompson JD, Gibson TJ, Higgins DG: Clustal W and Clustal X version 2.0. Bioinformatics 2007, 23(21):2947-2948.

47. Pfaffl MW: A new mathematical model for relative quantification in real-time RT-PCR. Nucleic Acids Res 2001, 29(9):e45.

48. Vandesompele J, De Preter K, Pattyn F, Poppe B, Van Roy N, De Paepe A Speleman F: Accurate normalization of real-time quantitative RT-PCR data by geometric averaging of multiple internal control genes. Genome Biol 2002, 3:7. research0034.0031 - research0034.0011.

49. Untergasser A, Cutcutache I, Koressaar T, Ye J, Faircloth BC, Remm M, Rozen SG: Primer3 - new capabilities and interfaces. Nucleic Acids Res 2012, 40(15):e115. 
50. Roxas VP, Smith RK, Allen ER, Allen RD: Overexpression of glutathione S-transferase/glutathioneperoxidase enhances the growth of transgenic tobacco seedlings during stress. Nat Biotechnol 1997, 15(10):988-991.

51. Sun W, Van Montagu M, Verbruggen N: Small heat shock proteins and stress tolerance in plants. Biochim Biophys Acta (BBA) Gene Struct Express 2002, 1577(1):1-9.

52. Hassan S, Mathesius U: The role of flavonoids in root-rhizosphere signalling: opportunities and challenges for improving plant-microbe interactions. J Exp Bot 2012, 63(9):3429-3444.

53. Abogadallah GM: Insights into the significance of antioxidative defense under salt stress. Plant Signal Behav 2010, 5(4):369-374.

54. Barbier-Brygoo H, De Angeli A, Filleur S, Frachisse J-M, Gambale F, Thomine S, Wege S: Anion channels/transporters in plants: from molecular bases to regulatory networks. Annu Rev Plant Biol 2011, 62(1):25-51.

55. Tsay YF, Chiu CC, Tsai CB, Ho CH, Hsu PK: Nitrate transporters and peptide transporters. Febs Lett 2007, 581(12):2290-2300.

56. Li JY, Fu YL, Pike SM, Bao J, Tian W, Zhang Y, Chen CZ, Zhang Y, Li HM, Huang J, Li LG, Schroeder Jl, Gassmann W, Gong JM: The Arabidopsis nitrate transporter NRT1.8 functions in nitrate removal from the xylem sap and mediates cadmium tolerance. Plant Cell 2010, 22(5):1633-1646.

57. Lin SH, Kuo HF, Canivenc G, Lin CS, Lepetit M, Hsu PK, Tillard P, Lin HL, Wang YY, Tsai CB, Gojon A, Tsay YF: Mutation of the Arabidopsis NRT1.5 nitrate transporter causes defective root-to-shoot nitrate transport. Plant Cell 2008, 20(9):2514-2528.

58. Chen CZ LVXF, Li JY, Yi HY, Gong JM: Arabidopsis NRT1.5 is another essential component in the regulation of nitrate reallocation and stress tolerance. Plant Physiol 2012, 159(4):1582-1590.

59. Segonzac C, Boyer JC, Ipotesi E, Szponarski W, Tillard P, Touraine B, Sommerer N, Rossignol M, Gibrat R: Nitrate efflux at the root plasma membrane: identification of an Arabidopsis excretion transporter. Plant Cell 2007, 19(11):3760-3777.

60. Sasaki T, Yamamoto Y, Ezaki B, Katsuhara M, Ahn SJ, Ryan PR, Delhaize E, Matsumoto $\mathrm{H}$ : A wheat gene encoding an aluminum-activated malate transporter. Plant J 2004, 37(5):645-653.

61. Piñeros MA, Cançado GMA, Maron LG, Lyi SM, Menossi M, Kochian LV: Not all ALMT1-type transporters mediate aluminum-activated organic acid responses: the case of ZmALMT1 - an anion-selective transporter. Plant J 2008, 53(2):352-367.

62. De Angeli A, Zhang J, Meyer S, Martinoia E: AtALMT9 is a malate-activated vacuolar chloride channel required for stomatal opening in Arabidopsis. Nat Commun 2013, 4:1804

63. Conn SJ, Gilliham M, Athman A, Schreiber AW, Baumann U, Moller I, Cheng N-H, Stancombe MA, Hirschi KD, Webb AAR, Burton R, Kaiser BN, Tyerman SD, Leigh RA: Cell-specific vacuolar calcium storage mediated by CAX regulates apoplastic calcium concentration, gas exchange, and plant productivity in Arabidopsis. Plant Cell Online 2011, 23(1):240-257.

64. Zhao J, Barkla BJ, Marshall J, Pittman JK, Hirschi KD: The Arabidopsis cax3 mutants display altered salt tolerance, $\mathrm{pH}$ sensitivity and reduced plasma membrane $\mathrm{H}^{+}$-ATPase activity. Planta 2008, 227(3):659-669.

65. Geisler M, Frangne N, Gomès E, Martinoia E, Palmgren MG: The ACA4 gene of Arabidopsis encodes a vacuolar membrane calcium pump that improves salt tolerance in yeast. Plant Physiol 2000, 124(4):1814-1827.

66. Brandt B, Brodsky DE, Xue S, Negi J, Iba K, Kangasjärvi J, Ghassemian M, Stephan $A B, H u H$, Schroeder Jl: Reconstitution of abscisic acid activation of SLAC1 anion channel by CPK6 and OST1 kinases and branched ABI1 PP2C phosphatase action. Proc Natl Acad Sci 2012, 109(26):10593-10598.

67. Hedrich R: Ion channels in plants. Physiol Rev 2012, 92(4):1777-1811.

68. Song W-Y, Park J, Mendoza-Cózatl DG, Suter-Grotemeyer M, Shim D, Hörtensteiner S, Geisler M, Weder B, Rea PA, Rentsch D, Schroeder Jl, Lee Y, Martinoia E: Arsenic tolerance in Arabidopsis is mediated by two ABCC-type phytochelatin transporters. Proc Natl Acad Sci 2010, 107(49):21187-21192.

69. Lee EK, Kwon M, Ko J-H, Yi H, Hwang MG, Chang S, Cho MH: Binding of sulfonylurea by AtMRP5, an Arabidopsis multidrug resistance-related protein that functions in salt tolerance. Plant Physiol 2004, 134(1):528-538.

70. Cotsaftis O, Plett D, Johnson AAT, Walia H, Wilson C, Ismail AM, Close TJ, Tester M, Baumann U: Root-specific transcript profiling of contrasting rice genotypes in response to salinity stress. Mol Plant 2011, 4(1):25-41.

71. Viehweger K, Dordschbal B, Roos W: Elicitor-activated phospholipase A2 generates lysophosphatidylcholines that mobilize the vacuolar $\mathrm{H}^{+}$pool for $\mathrm{pH}$ signaling via the activation of $\mathrm{Na}^{+}$-dependent proton fluxes. Plant Cell Online 2002, 14(7):1509-1525.
72. Cramer G, Urano K, Delrot S, Pezzotti M, Shinozaki K: Effects of abiotic stress on plants: a systems biology perspective. BMC Plant Biol 2011, 11(1):163.

73. Mittler R, Vanderauwera S, Suzuki N, Miller G, Tognetti VB, Vandepoele K, Gollery M, Shulaev V, Van Breusegem F: ROS signaling: the new wave? Trends Plant Sci 2011, 16(6):300-309.

74. Ismail A, Riemann M, Nick P: The jasmonate pathway mediates salt tolerance in grapevines. J Exp Bot 2012, 63(5):2127-2139.

75. Walia H, Wilson C, Condamine P, Ismail A, Xu J, Cui X, Close T: Array-based genotyping and expression analysis of barley cv. Maythorpe Golden Promise. BMC Genom 2007, 8(1):87.

76. Walia H, Wilson C, Wahid A, Condamine P, Cui X, Close T: Expression analysis of barley (Hordeum vulgare L.) during salinity stress. Funct Integrative Genom 2006, 6(2):143-156.

77. Wang Y, Yang L, Zheng Z, Grumet R, Loescher W, Zhu J-K, Yang P, Hu Y, Chan Z: Transcriptomic and physiological variations of three Arabidopsis ecotypes in response to salt stress. PLOS ONE 2013, 8(7):e69036.

78. Geiger D, Maierhofer T, AL-Rasheid KAS, Scherzer S, Mumm P, Liese A, Ache P, Wellmann C, Marten I, Grill E, Romeis T, Hedrich R: Stomatal closure by fast abscisic acid signaling is mediated by the guard cell anion channel SLAH3 and the receptor RCAR1. Sci Signal 2011, 4(173):ra32.

79. Meyer S, Mumm P, Imes D, Endler A, Weder B, Al-Rasheid KAS, Geiger D, Marten I, Martinoia E, Hedrich R: AtALMT12 represents an R-type anion channel required for stomatal movement in Arabidopsis guard cells. Plant J 2010, 63(6):1054-1062

80. White PJ, Broadley MR: Chloride in soils and its uptake and movement within the plant: a review. Ann Bot 2001, 88(6):967-988.

81. Imes D, Mumm P, Böhm J, Al-Rasheid KAS, Marten I, Geiger D, Hedrich R: Open stomata 1 (OST1) kinase controls R-type anion channel QUAC1 in Arabidopsis guard cells. Plant J 2013, 74(3):372-382.

82. Gutermuth T, Lassig R, Portes M-T, Maierhofer T, Romeis T, Borst J-W, Hedrich R, Feijó JA, Konrad KR: Pollen tube growth regulation by free anions depends on the interaction between the anion channel SLAH3 and calcium-dependent protein kinases CPK2 and CPK20. Plant Cell Online 2013, 25(11):4525-4543.

83. Sykes SR: Variation in chloride accumulation by hybrid vines from crosses involving the cultivars Ramsey, Villard Blanc, and Sultana. Am J Enol Vitic 1985, 36:30-37.

84. Deane-Drummond CE: A comparison of regulatory effects of chloride on nitrate uptake, and of nitrate on chloride uptake into Pisum sativum seedlings. Physiol Plant 1986, 66(1):115-121.

85. Glass ADM, Siddiqi MY: Nitrate inhibition of chloride influx in barley implications for a proposed chloride homeostat. J Exp Bot 1985, 36(165):556-566.

86. Jossier M, Kroniewicz L, Dalmas F, Le Thiec D, Ephritikhine G, Thomine S Barbier-Brygoo H, Vavasseur A, Filleur S, Leonhardt N: The Arabidopsis vacuolar anion transporter, AtCLCC, is involved in the regulation of stomatal movements and contributes to salt tolerance. Plant J 2010, 64(4):563-576.

87. Li W-YF, Wong F-L, Tsai S-N, Phang T-H, Shao G, Lam H-M: Tonoplastlocated $\mathrm{GmCLC1}$ and $\mathrm{GmNHX} 1$ from soybean enhance $\mathrm{NaCl}$ tolerance in transgenic bright yellow (BY)-2 cells. Plant Cell Environ 2006, 29(6):1122-1137.

88. Nakamura A, Fukuda A, Sakai S, Tanaka Y: Molecular cloning, functional expression and subcellular localization of two putative vacuolar voltagegated chloride channels in rice (Oryza sativa L.). Plant Cell Physiol 2006, 47(1):32-42.

89. Wei Q, Liu Y, Zhou G, Li Q, Yang C, Peng SA: Overexpression of CsCLCC, a chloride channel gene from Poncirus trifoliata, enhances salt tolerance in Arabidopsis. Plant Mol Biol Report 2013, 31:1548-1557.

90. Von der Fecht-Bartenbach J, Bogner M, Dynowski M, Ludewig U: CLC-bmediated $\mathrm{NO}_{3}^{-} / \mathrm{H}^{+}$exchange across the tonoplast of Arabidopsis vacuoles. Plant Cell Physiol 2010, 51(6):960-968

91. De Angeli A, Monachello D, Ephritikhine G, Frachisse JM, Thomine S, Gambale $\mathrm{F}$, Barbier-Brygoo $\mathrm{H}$ : The nitrate/proton antiporter AtCLCa mediates nitrate accumulation in plant vacuoles. Nature 2006, 442(7105):939-942.

92. Bergsdorf E-Y, Zdebik AA, Jentsch TJ: Residues important for nitrate/proton coupling in plant and mammalian CLC transporters. J Biol Chem 2009, 284(17):11184-11193.

93. Wege $\mathrm{S}$, Jossier M, Filleur S, Thomine S, Barbier-Brygoo H, Gambale F, De Angeli A: The proline 160 in the selectivity filter of the Arabidopsis $\mathrm{NO}_{3}^{-} / \mathrm{H}^{+}$ exchanger AtCLCa is essential for nitrate accumulation in planta. Plant $J$ 2010, 63(5):861-869. 
94. Marmagne A, Vinauger-Douard M, Monachello D, de Longevialle AF, Charon C, Allot M, Rappaport F, Wollman F-A, Barbier-Brygoo H, Ephritikhine G: Two members of the Arabidopsis CLC (chloride channel) family, AtCLCe and AtCLCf, are associated with thylakoid and Golgi membranes, respectively. J Exp Bot 2007, 58(12):3385-3393.

95. Liu KH, Tsay YF: Switching between the two action modes of the dualaffinity nitrate transporter CHL1 by phosphorylation. J Article 2003, 22(5): 1005-1013.

96. Lee SC, Lan W, Buchanan BB, Luan S: A protein kinase-phosphatase pair interacts with an ion channel to regulate $A B A$ signaling in plant guard cells. Proc Natl Acad Sci 2009, 106(50):21419-21424.

97. Wege S, De Angeli A, Droillard M-J, Kroniewicz L, Merlot S, Cornu D, Gambale F, Martinoia E, Barbier-Brygoo H, Thomine S, Leonhardt N, Filleur S: Phosphorylation of the vacuolar anion exchanger AtCLCa is required for the stomatal response to abscisic acid. Sci Signal 2014, 7(333):ra65.

98. Tregeagle JM, Tisdall JM, Blackmore DH, Walker RR: A diminished capacity for chloride exclusion by grapevine rootstocks following long-term saline irrigation in an inland versus a coastal region of Australia. Aust J Grape Wine Res 2006, 12(3):178-191.

99. Vandeleur RK, Mayo G, Shelden MC, Gilliham M, Kaiser BN, Tyerman SD: The role of plasma membrane intrinsic protein aquaporins in water transport through roots: diurnal and drought stress responses reveal different strategies between isohydric and anisohydric cultivars of grapevine. Plant Physiol 2009, 149(1):445-460.

doi:10.1186/s12870-014-0273-8

Cite this article as: Henderson et al:: Shoot chloride exclusion and salt tolerance in grapevine is associated with differential ion transporter expression in roots. BMC Plant Biology 2014 14:273.

\section{Submit your next manuscript to BioMed Central and take full advantage of:}

- Convenient online submission

- Thorough peer review

- No space constraints or color figure charges

- Immediate publication on acceptance

- Inclusion in PubMed, CAS, Scopus and Google Scholar

- Research which is freely available for redistribution 